\title{
52. SEDIMENTATION AND SEDIMENTARY PROCESSES IN THE LAU BACKARC BASIN: RESULTS FROM LEG $135^{\prime}$
}

\author{
R.G. Rothwell, ${ }^{2}$ U. Bednarz, ${ }^{3}$ R. Bøe, ${ }^{4}$ P.D. Clift, ${ }^{5}$ R.A. Hodkinson, ${ }^{6}$ \\ J.K. Ledbetter, ${ }^{7}$ C.E. Pratt, ${ }^{8}$ and S. Soakai ${ }^{9}$
}

\begin{abstract}
Six sites were drilled during Ocean Drilling Program Leg 135 in the western Lau backarc basin (Sites 834-839). These sites are all located in basins within a horst-and-graben terrain and form an approximate transect across the rifted arc basement onto crust considered to have been formed at the Eastern Lau Spreading Center. The sedimentary succession recovered from these backarc sites ranges in age from the upper Miocene to the Holocene and consists primarily of a lower succession of volcaniclastic sediment gravity-flow deposits interbedded with hemipelagic clayey nannofossil oozes and nannofossil clays, overlain by an upper succession of hemipelagic clayey nannofossil oozes, with minor calcareous turbidites. The volcaniclastic sediment gravity-flow deposits are predominantly massive, proximal vitric sands and silts, and are mainly derived from the basement ridges that separate the individual sub-basins that form the floor of the western Lau Basin.

The sedimentary and topographic evidence suggests that Pliocene sedimentation in the Lau Basin was characterized by proximal volcaniclastic sedimentation around intrabasinal seamount volcanoes. In contrast Pleistocene sedimentation was mainly hemipelagic with the deposition of clayey nannofossil ooze. However, some parts of the backarc basin were affected by marked instability throughout the Pleistocene with extensive emplacement of muddy debris flows, rafted blocks, and thick mud turbidites. Some episodes of instability may correlate with the approach and passing of the Central Lau propagator.

Geochemical analysis of individual glass grains from the volcaniclastic beds shows a subdivision of the backarc basin into three areas: a western group (Sites 834-835) that shows a broad spectrum of total silica values; a central group (Sites 837-839) that shows an approximately bimodal total silica population; and Site 836, which has a strong bias to low-silica glasses. This geochemical subdivision confirms the sedimentary evidence for depositional compartmentalization of the basin during the Pliocene.

The hemipelagic sediments in the Lau Basin are pervasively stained by hydrothermally derived iron and manganese oxyhydroxides. A similar general trend in downhole variability in the hydrothermal oxide sediment component is seen at all backarc sites, with the possible exception of Site 836. A period of increased hydrothermal input occurs at depth at all sites, whereas above and below this is a general trend of decreasing hydrothermal input. This relationship probably indicates that a period of time was required for a hydrothermal system to become fully established and record its maximum input to the sedimentary succession. Such a trend is in marked contrast to mid-ocean spreading centers, such as the East Pacific Rise, where a general uphole decrease away from basement results from the increasing distance of the site with respect to the hydrothermal plume source caused by crustal spreading.
\end{abstract}

\section{INTRODUCTION}

During Ocean Drilling Program (ODP) Leg 135, six sites were drilled in the western Lau backarc basin (Sites 834-839; see Fig. 1). These sites form an approximate transect across the rifted arc basement that floors the western Lau Basin onto crust considered to have been formed at the Eastern Lau Spreading Center (ELSC). Although the main drilling objectives were to sample the igneous basement rocks and to determine the age of the beginning of opening of the

'Hawkins. J.. Parson. L... Allan. J.. et al.. 1994. Proc. ODP. Sci. Results, 135: College Station, TX (Ocean Drilling Program).

Institute of Oceanographic Sciences. Wormley, Godalming, Surrey, GU8 5UB, United Kingdom.

${ }^{3}$ Forschungszentrum für Marine Geowissenschaften. Christian-Albrechts-Universită zu Kiel. Postfach 102148. Wischhofstraße 1-3. D-2300. Kiel 14. Federal Republic of Germany (present address: Das Baugrund Institut. Brosshauser Strasse 27. 5650 Solingen 11. Federal Republic of Germany)

${ }_{5}^{4}$ Geological Survey of Norway, P.O. Box 3006, Lade, N-7002 Trondheim. Norway.

${ }^{5}$ Grant Institute, Department of Geology and Geophysics, University of Edinburgh. West Mains Road, Edinburgh. EH9 3JW, United Kingdom (present address: Ocean Drilling Program. Texas A\&M University Research Park. 1000 Discovery Drive. College Station. TX 77845-9547. U.S.A.).

${ }^{6}$ Department of Geology. Imperial College. Prince Consort Road. London, SW7 2BP, United Kingdom.

'Department of Geosciences, University of Tulsa, 600 South College Avenue, Tulsa. OK 74104. U.S.A. (present address: Ocean Drilling Program. Texas A\&M University Research Park. 1000 Discovery Drive, College Station. TX 77845-9547. U.S.A.)

${ }^{\mathrm{x}}$ Mineral Resources Department, Private Mail Bag. Suva. Fiji.

${ }^{9}$ Ministry of Lands. Surveys and Natural Resources. P.O. Box 5. Nukualofa, Tonga. backarc basin, an important objective was to obtain sedimentary, paleontologic, and paleomagnetic records of the basin fill.

The floor of the western Lau Basin consists of a number of small. elongated, partially sediment-filled sub-basins separated by uplifted. elongated basement ridges and highs that have only a thin sediment cover (Parson, Hawkins, Allan, et al., 1992). Sites 834-839 were drilled within these sub-basins. Sites 834 and 835 were drilled in two separate, but adjacent, sub-basins, $48 \mathrm{~km}$ apart, between 100 and 200 km east of the Lau Ridge (Fig. 1) whereas Sites 836-839 were drilled about $200 \mathrm{~km}$ to the southeast of Sites 834 and 835 , in three faultbounded sub-basins on the western flank of the ELSC. These four sites are less than $90 \mathrm{~km}$ apart. Sites 838 and 839 were drilled within the same sub-basin.

In this synthesis paper, we present and analyze the sedimentologic results obtained during Leg 135 to give an overview of the pattern of sedimentation within the backarc basin since its formation. This synthesis is based on the sedimentary data set recovered during the drilling leg (Parson. Hawkins, and Allan, et al., 1992) and the sedimentologic specialty papers presented in this volume, principally Bednarz and Schmincke, Clift and Dixon, Hodkinson and Cronan, Griffiths et al., Rothwell et al., Thomson et al., and Parson et al. (all in this volume).

\section{SEDIMENTARY SUCCESSION}

The lithostratigraphy of the backarc drill sites is summarized in Figure 2, which shows the stratigraphic columns of each site presented with age as the vertical scale. The ages were calculated from 


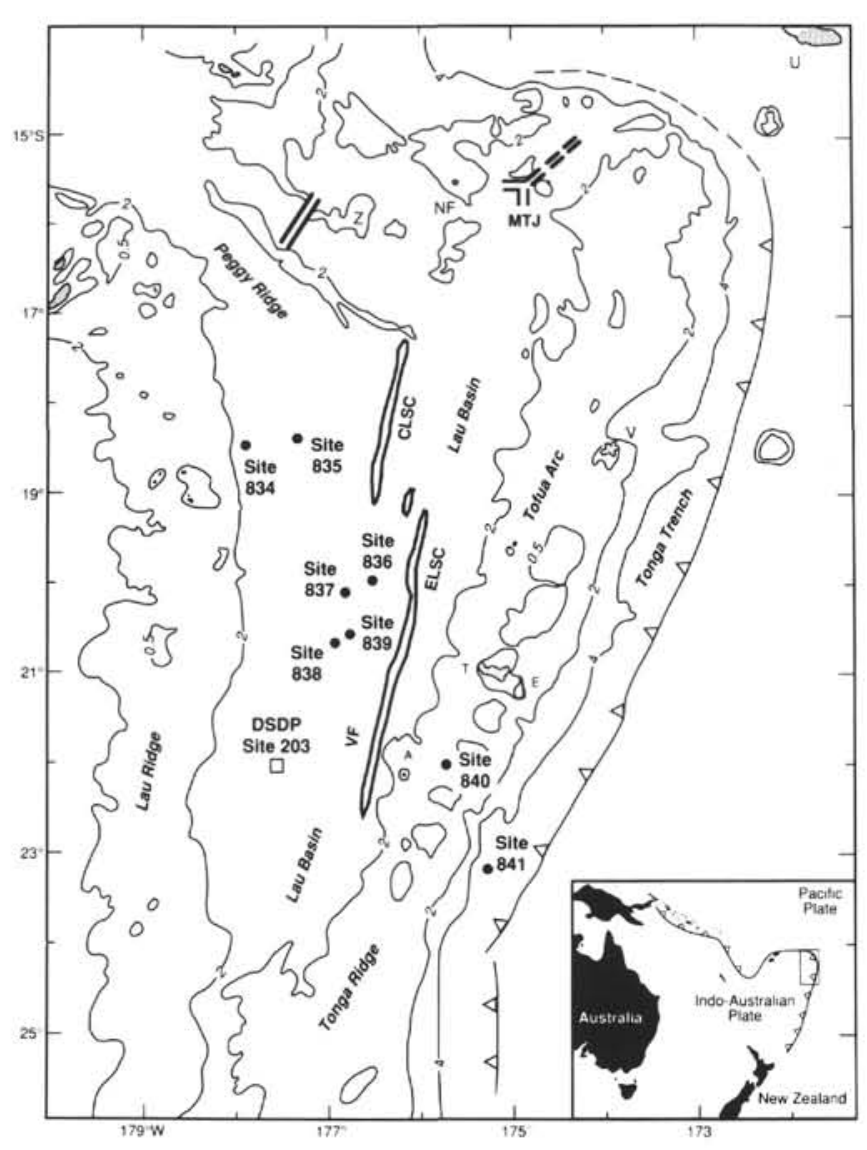

Figure 1. Location map of Leg 135 sites drilled in the Lau backarc basin. western Pacific. Also shown are the main geological features of the Tonga Trench and Lau Basin system. Islands shown are 'Ata (A). Tongatapu (T), 'Eau (E), Vava'u (V), Niuafo'ou (NF), and Upolu (U). Locations of the Central Lau (CLSC) and Eastern Lau spreading centers (ELSC), Zephyr Shoal (Z), Valu Fa Ridge (VF) and Mangatolu Triple Junction (MTJ) are also shown.

average hemipelagic sedimentation rates (considered to be about 1.5 $\mathrm{cm} / \mathrm{k} . \mathrm{y}^{-1}$ by Rothwell et al. [this volume] and Reich et al. [1990]) constrained by shipboard biostratigraphic and paleomagnetic data. Allochthonous beds within the sedimentary succession were identified on compositional and textural criteria for the volcaniclastic beds and on the criteria discussed by Rothwell et al. (this volume) for calcareous mud turbidites.

Atwofold division of the sedimentary succession overlying basaltic basement in the Lau backarc basin can be recognized. This consists of a lower interval of volcaniclastic sediment gravity-flow deposits interbedded with hemipelagic clayey nannofossil sediments and nannofossil clays (termed lithologic Units II and III in Parson, Hawkins, Allan, et al., 1992; Fig. 2). This is overlain by an upper interval of hemipelagic clayey nannofossil ooze with minor calcareous turbidites (termed lithologic Unit I at Sites 834, 835, 837, 838, and 839 and Subunit IA at Site 836 in Parson, Hawkins, Allan, et al., 1992; Fig. 2). All the backarc sites show this same overall pattern of sedimentation. The thicknesses of the lower volcaniclastic succession and the overlying clayey nannofossil ooze succession vary across the basin. The volcaniclastic sediment gravity-flow deposits are predominantly massive proximal vitric sands and silts (Parson, Hawkins, Allan, et al., 1992) that were probably derived from intrabasin volcanic seamounts and from the basement ridges and highs that separate the sub-basins (Bednarz and Schmincke, this volume; Clift and Dixon, this volume). The tran- sition between the lower volcaniclastic-dominated succession and the upper clayey nannofossil ooze succession is typically abrupt and occurs at different ages at the different backarc sites (Fig. 2). This, together with the proximal character of the volcaniclastic sediments of the lower succession, suggests that sedimentation during, and immediately following, basin formation was a localized process, with no suggestion of one major sediment source for the entire basin.

\section{Site 834}

Site 834 was drilled in a small sub-basin about $100 \mathrm{~km}$ east of the Lau Ridge and about $150 \mathrm{~km}$ west of the Central Lau Spreading Center (Fig. 1). The sub-basin has an area of approximately $500 \mathrm{~km}^{2}$ and is surrounded by relatively gentle slopes with gradients on the order of $3^{\circ}$. The sediments overlying basaltic basement at Site 834 consists of $112.5 \mathrm{~m}$ of clayey nunnofossil oozes and mixed sediments (using the sediment classification of Mazzullo et al., 1987), nannofossil clays, turbiditic foraminiferal sands, and turbiditic sands and silts (Fig. 2). Volcaniclastic turbidites are absent from the interval $0-42 \mathrm{~m}$ below seafloor (mbsf), but then increase both in frequency and thickness downhole, especially below $78 \mathrm{mbsf}$. Paleomagnetic, biostratigraphic, and petrologic data and consideration of background hemipelagic sedimentation rates (Parson, Hawkins, Allan, et al., 1992, pp. 85-180; Rothwell et al., this volume) suggest that the sub-basin was formed between 4.4 and $5.6 \mathrm{Ma}$, a period marked by the eruption of basement basalts. Extrusive volcanism associated with basin formation ceased at about $4.4 \mathrm{Ma}$. Between 3.8 and $4.4 \mathrm{Ma}$, sedimentation was primarily volcaniclastic with the deposition of thick volcanic sands and silts. These have been interpreted on textural criteria as probably being deposited by turbidity currents and other types of sediment gravity flows (Parson, Hawkins, Allan, et al., 1992, pp. 85-180). These sands and silts typically comprise up to $90 \%$ felsic glass shards, the remainder consisting of clay-sized material and foraminifers. Between 2.4 and $3.8 \mathrm{Ma}$, the deposition of volcaniclastic beds continued; however, during this period, volcaniclastic sedimentation decreased markedly. Volcaniclastic beds became thinner and emplacement less frequent with time, ceasing at about $2.4 \mathrm{Ma}$. Deposition in the sub-basin was largely hemipelagic from 0.2 to $2.4 \mathrm{Ma}$, with some calcareous turbidites (Fig. 2). Since $0.2 \mathrm{Ma}$, sedimentation was characterized by deposition of hemipelagic clayey nannofossil oozes with several episodes of calcareous turbidite emplacement (Rothwell et al., this volume).

\section{Site 835}

Site 835 was drilled in a fault-bounded graben, $48 \mathrm{~km}$ to the east of Site 834 (Fig. 1). The graben is asymmetric with a major continuous fault scarp forming the west wall and a more complex and less continuous set of nested fault structures forming the east flank (Parson et al., this volume). The scarps rise above the basin floor by $1400 \mathrm{~m}$ to the west and by $1100 \mathrm{~m}$ to the east with steep gradients, on the order of $10^{\circ}$ to the west, $4^{\circ}-9^{\circ}$ to the south, and $10^{\circ}-30^{\circ}$ to the east. The basin has an approximate area of $160-200 \mathrm{~km}^{2}$. Site 835 represents a continuous sedimentary succession consisting of $155 \mathrm{~m}$ of clayey nannofossil ooze and mixed sediments, foraminiferal sands, mudclast conglomerates, and volcanic silts that consist largely of felsic volcanic glass (Fig. 2; Parson, Hawkins, Allan, et al., 1992, pp. 181-245). Most of the volcaniclastic beds have been interpreted as proximal sediment gravity-flow deposits. Volcanic silts appear with increasing frequency below 130 mbsf but most do not reach the thickness of those seen toward the base of Hole 834A. The upper 130 $\mathrm{m}$ of the sediment column at Site $835(0-2.9 \mathrm{Ma})$ consists mainly of redeposited sediments (Rothwell et al., this volume). Several beds of mud-clast conglomerate, interpreted as muddy debris-flow deposits, suggest episodes of instability during deposition at 9-10, 13-14, $16-18,30-37,40-41,56-58,66.5-67$, and 122-128 mbsf. These form parts of single or multiple slide complexes that are commonly 


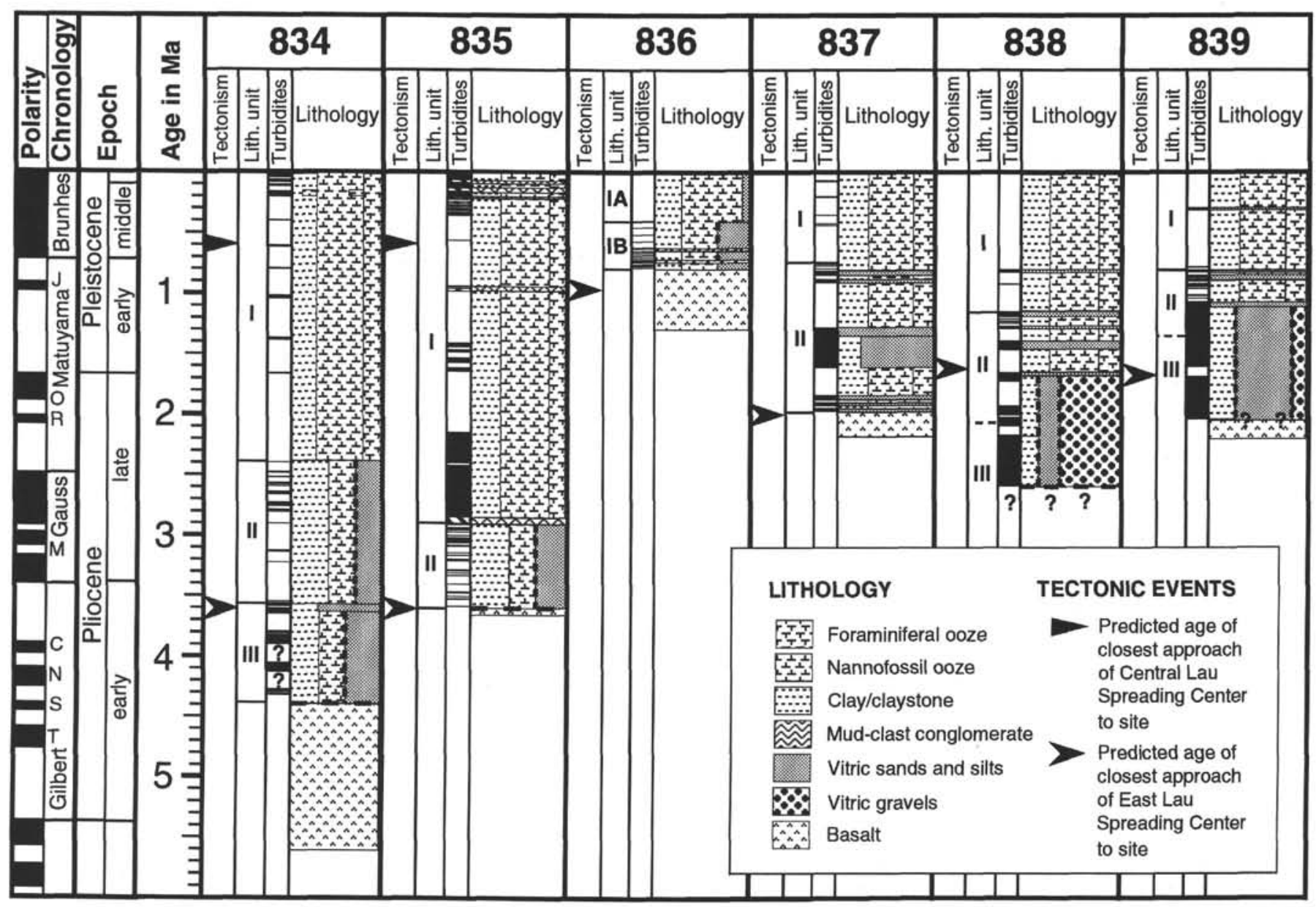

Figure 2. Generalized lithologic columns drilled at the Lau Basin backarc sites, presented with age (in Ma) as the vertical scale. The ages of sedimentary horizons were calculated from hemipelagic accumulation rates constrained by shipboard biostratigraphic and paleomagnetic data. Times of emplacement of allochthonous beds are shown in black in the "Turbidites" column. These were identified on the basis of compositional and textural criteria for the volcaniclastic beds as well as by the criteria discussed in Rothwell et al. (this volume) for calcareous mud turbidites. The lithologic units identified by Parson. Hawkins, Allan, et al. (1992) and the predicted ages of the closest approach of the Central and Eastern Lau propagators to the sites are also shown. Thick dashed vertical lines indicate that the lithologies shown are interbedded.

overlain by thick ungraded turbidite muds. Some of these slide complexes contain coherent rafted blocks of older hemipelagic sediments, probably derived from catastrophic failure on the basin flanks, possibly involving retrogressive sliding (Rothwell et al., this volume).

\section{Site 836}

Site 836 was drilled on oceanic crust generated at the ELSC, which is about $0.8 \mathrm{Ma}$ in age according to the magnetic anomaly data. The sediment thickness is only $20 \mathrm{~m}$ and consists of a succession of clayey nannofossil ooze with interbedded volcaniclastic gravity-flow deposits of predominantly vitric sands and silts, rare pyroclastic tephra, and thick-bedded mafic hyaloclastites (Fig. 2; Parson, Hawkins, Allan, et al., 1992, pp. 247-287). Volcaniclastic sediment gravity-flow deposits are very rare in the interval from 0 to 6 mbsf. The only volcaniclastic beds that occur in this interval are thin ash layers, most of which are probably primary fallout tephras. Assuming an average background hemipelagic sedimentation rate of $1.5 \mathrm{~cm} / \mathrm{k} . \mathrm{y}^{-1}$ (Reich et al., 1990; Rothwell, et al., this volume), this largely hemipelagic pelagic interval may represent the time period $0-0.4 \mathrm{Ma}$. Thin- to medium-bedded volcaniclastic sand and silt gravity-flow deposits occur at a much greater frequency below $12 \mathrm{mbsf}$, suggesting that after about $0.78 \mathrm{Ma}$, emplacement of volcaniclastic beds increased markedly in frequency.

\section{Site 837}

Site 837 was drilled in a small, sublinear, partly sediment-filled sub-basin in the central Lau Basin about $180 \mathrm{~km}$ east of the Lau Ridge and approximately $70 \mathrm{~km}$ west of the axial rift zone of the ELSC (Fig. 1). The sediments consist of $82 \mathrm{~m}$ of clayey nannofossil ooze and vitric volcaniclastic sediments that range from Holocene to late Pliocene in age (Fig. 2; Parson, Hawkins, Allan, et al., 1992, pp. 289-335). The succession comprises a thick lower interval of thick- to very thickbedded, normally graded, vitric sands and silts deposited by sediment gravity flows. These beds have been interpreted as proximal deposits because of the angularity and delicacy of the shards and their coarse grain size (Parson, Hawkins, Allan, et al., 1992, pp. 289-335). They may have been deposited in rapid succession as little hemipelagic sediment is present between them, although this may reflect basal scour during emplacement. This volcaniclastic-dominated lower interval is overlain by just over $13 \mathrm{~m}$ of clayey nannofossil ooze that contains rare beds of graded foraminiferal oozes and thin vitric silts. Of this upper interval, detailed lithologic logging has identified allochthonous beds on the basis of textural and structural criteria (Fig. 2). This shows that slightly more than $11 \mathrm{~m}$ of the $13 \mathrm{~m}$ represents hemipelagic accumulation, with an estimated age of $760-770 \mathrm{ka}$ for the base of the predominantly hemipelagic unit. 


\section{Site 838}

Site 838 was drilled in an irregularly shaped, partly sediment-filled trough, trending approximately northeast-southwest on the western flank of the ELSC, about $50 \mathrm{~km}$ to the south of Site 837 (Fig. 1). The flanking ridges shoal by up to a kilometer in water depth. The sediments consist of $103 \mathrm{~m}$ of volcaniclastic deposits and clayey nannofossil oozes, of which the uppermost $98.7 \mathrm{~m}$ was continuously cored (Parson, Hawkins, Allan, et al., 1992, pp. 337-395). Only a total of $4.82 \mathrm{~m}$ of sediment was recovered from the interval from 98.7 to $259.2 \mathrm{mbsf}$. The succession can be divided into two sequences (Fig. 2). The lower sequence is at least $236 \mathrm{~m}$ thick and consists of a series of thick volcanic gravel megabeds that usually fine upward into vitric sandy gravels and vitric sands. These are interpreted as proximal sediment gravity-flow deposits on the basis of their coarse grain size and angularity of the grains, with delicate shard morphologies commonly preserved in the vitric sands and silts. They are interbedded with thin to thick beds of hemipelagic clayey nannofossil ooze. Although recovery was sporadic below $98.7 \mathrm{mbsf}$, the recovered sediments suggest a similar sequence to the volcaniclastic-dominated interval continuously cored between 23.04 and $98.7 \mathrm{mbsf}$. The upper sequence consists of $23 \mathrm{~m}$ of almost wholly hemipelagic clayey nannofossil ooze, except for a thick-bedded sandy turbidite from 15.6 to $16.3 \mathrm{mbsf}(150-155 \mathrm{ka})$ and a thick bed of mud-clast conglomerate from 2.30 to 3.77 mbsf ( $0.9 \mathrm{Ma}$ ).

\section{Site 839}

Site 839 was drilled in a deeper part of the same basin as Site 838 , about $20 \mathrm{~km}$ to the northeast. The sediments consist of nearly $215 \mathrm{~m}$ of clayey nannofossil ooze, vitric sands and silts, volcanic gravels, and rare pyroclastic ashes (Fig. 2; Parson, Hawkins, Allan, et al., 1992, pp. 397-487). The overall basic sedimentary pattern is the same as at the other backarc sites, with a thick (180-200 m) lower volcaniclasticdominated interval consisting of a series of generally thick- to very thick-bedded, vitric sands and silts with some hemipelagic ooze interbeds and an upper sequence that consists almost exclusively of hemipelagic clayey nannofossil ooze (Fig. 2). Recovery between 99.5 and 214 mbsf was poor, but the sediment that was recovered (mainly volcanic gravel and vitric sands and silts) suggests that this interval is a continuation of the lower volcaniclastic-dominated interval. Sedimentation rates and shipboard paleomagnetic and biostratigraphic dating suggest that the boundary between the two units occurred at about $0.8 \mathrm{Ma}$.

\section{HEMIPELAGIC SEDIMENTS AT SITES 834-839}

Hemipelagic sediments within the backarc basin comprise clayey nannofossil oozes, clayey nannofossil mixed sediments, and nannofossil clays according to the sediment classification of Mazzullo et al. (1987). The proportion of clay-grade and noncarbonate material within the hemipelagic sediments tends to increase downhole (Fig. 2). Highresolution lithostratigraphic studies of clayey nannofossil oozes at Sites 834 and 835 by Rothwell et al. (this volume) suggest an average hemipelagic sedimentation rate of $1.5 \mathrm{~cm} / 1000 \mathrm{yr}$, the same figure as reported by Reich et al. (1990) from studies of piston and gravity cores from the Lau Basin.

The hemipelagic deposits consist of about $30 \%-60 \%$ clay-sized material, the rest of the sediment is composed primarily of calcareous nannofossils (47-70 vol\%) and a much smaller percentage of planktonic foraminifers $(3-10 \mathrm{vol} \%)$ on the basis of petrographic analysis. Calcium carbonate values range from $40 \%$ to $75 \% \mathrm{CaCO}_{3}$ with the lower values characteristic of the deeper part of the sequence, although variability exists throughout the column. The upper part of the sediment column at all backarc sites consists of a clayey nannofossil ooze interval (lithologic Unit I, IA; Fig. 2), in which the ratio of clay-grade material to calcareous nannofossils remains fairly constant throughout. This uppermost lithologic unit, comprising largely hemi- pelagic drape, is of variable thickness across the backarc basin, but is thickest in the older parts of the basin (42 and 130 m thick at Sites 834 and 835, respectively). At Sites 836-839, in the central Lau Basin, this upper lithologic unit varies in thickness from 12 to $23 \mathrm{~m}$.

\section{Color of the Clayey Nannofossil Oozes}

Hemipelagic sediments at all the backarc sites are pervasively stained reddish brown to yellowish brown by hydrothermally derived iron and manganese oxyhydroxides (Parson, Hawkins, Allan, et al., 1992). These occur as small aggregates within the sediments and as surface coatings around the sedimentary grains. Such oxyhydroxides are widely distributed throughout the sediment of the Lau Basin (Cronan et al., 1986; Hodkinson et al., 1986; Reich et al., 1990). Typically, the clayey nannofossil oozes are stained brown to dark yellowish brown, having Munsell color values and chromas within the hue 10 YR. Typical colors are moderate (10 YR 5/4) to dark yellowish brown ( 10 YR 4/2). Thomson et al. (this volume) demonstrated that manganese $(\mathrm{Mn})$ is the dominant control on the brown coloration of the sediments, rather than iron $(\mathrm{Fe})$.

Sharply defined, lighter colored bands occur in some of the hemipelagic sediment, immediately beneath some (but by no means all) volcaniclastic and calcareous turbidites. Thomson et al. (this volume) showed these to be reduction haloes of a type previously identified in quite different turbidite/pelagic sequences on the Nares Abyssal Plain, Northwest Atlantic (Thomson et al., 1989). These haloes are attributed to the burial of labile organic carbon $\left(\mathrm{C}_{\mathrm{org}}\right)$ at the former sediment surface by turbidite emplacement. The oxyhydroxides of $\mathrm{Mn}$ and $\mathrm{Fe}$ are then used as electron acceptors to remineralize the $\mathrm{C}_{\text {org }}$ in the absence of oxygen, and $\mathrm{Mn}$ and $\mathrm{Fe}$ have profiles of characteristic shape within the haloes. Within the haloes, $\mathrm{Mn}$ is consistently at low levels and appears responsible for the color changes, whereas Fe has lowest values immediately under the turbidite, increases to a maximum, and then declines. Other elements (notably $\mathrm{Co}, \mathrm{Ni}$, and $\mathrm{Cu}$ ) are depleted in the reduction haloes, although their concentration-depth profiles are not identical to one another or with that for Mn. In contrast, $\mathrm{V}$ appears to have migrated into the haloes and to have been retained there (Thomson et al., this volume).

The development of reduction haloes beneath turbidites is generally uncommon at all the backarc sites with the exception of Sites 837 and 839 , where $30 \%-40 \%$ of turbidite events show the development of reduction haloes. If the turbidity current erodes the seabed during emplacement, so that it removes the near surface layer, which will contain the highest levels of reactive $\mathrm{C}_{\text {org }}$, it follows that haloes are unlikely to form. This is because that part of the sediment that usually contains the highest levels of $\mathrm{C}_{\text {org }}$ to drive the reduction process will have been removed. Haloes appear to be least common and at their thinnest at sites where the redeposited sediments are either unusually coarse grained or are the result of catastrophic failure of steep basin margins. The absence of haloes, therefore, suggests that emplacement of the overlying turbidites was erosive.

\section{Bioturbation of the Clayey Nannofossil Oozes}

Bioturbation of the Lau Basin sediments is typically low, reflecting the low organic carbon content of the sediment $(0.01 \%$, exceptionally up to $0.5 \%$ : Parson, Hawkins, Allan, et al., 1992). Many of the clayey nannofossil oozes, therefore, appear homogeneous or only weakly bioturbated.

\section{Redeposited Clayey Nannofossil Oozes}

Rothwell et al. (this volume) show that much of lithologic Unit I at Site 835 was redeposited. The redeposited beds consist of thickbedded clayey nannofossil ooze turbidites, coherent rafted blocks, and mud-clast conglomerates, interpreted as muddy debris-flow deposit (Fig. 3). Clayey nannofossil mud turbidites make up 55\% of the 
total clayey nannofossil ooze deposited at this site during the last 2.9 Ma. In contrast, sedimentation at Site 834 during this period was dominated by hemipelagic deposition (Fig. 4). Redeposited sediments comprise only $17 \%$ of the broadly time-equivalent thickness.

Rothwell et al. (this volume) identified four main episodes of instability during the last $3 \mathrm{Ma}$ at Site 835 from high-resolution lithostratigraphic studies. These occurred from 0 to $0.4,0.9$ to $1.0,1.4$ to 1.7 , and 2.1 to $2.9 \mathrm{Ma}$ and involved catastrophic slope failures (Figs. 3 and 5). Rothwell et al. discuss the distinguishing sedimentologic features of clayey nannofossil ooze turbidites and their differences to hemipelagic clayey nannofossil ooze (Table 1).

These catastrophic failures on the Site 835 basin flanks may have involved retrogressive sliding. The reasons for these periods of instability are unknown, although the most recent episode $(0-0.4 \mathrm{Ma})$ appears to correlate with the approach and passing of the Central Lau propagator, which passed the latitude of Sites 834 and 835 at about 0.5-0.6 Ma (Fig. 5; Parson and Hawkins, this volume). Tectonic activity and crustal readjustment following the passing of the Central Lau propagator at Site 834 may also be reflected in the marked increase in turbidite emplacement and the thickness and "sandiness" of the turbidites since $200 \mathrm{ka}$ (Fig. 4).

\section{Date of Transition Between Lithologic Units I and II}

The transition from a sedimentary regime characterized by primarily volcaniclastic sedimentation (lithologic Unit II, Sites 834, 835, and $837-839 /$ Subunit IB, Site 836 ; Fig. 2) to one dominated by hemipelagic sediments (lithologic Unit I, Sites 834, 835, and 837839/Subunit IA, Site 836; Fig. 2), occurred at different times at the backarc sites, except at Site 835 where much of the clayey nannofossil ooze in lithologic Unit I is redeposited. However, the boundary is generally abrupt, testifying to a sharp decrease in volcaniclastic material. At Site 834, this change occurs at 42 mbsf (about 2.3-2.4 Ma; Fig. $5)$. At Site 835, the change from the volcaniclastic-dominated lower sequence to one dominated by deposition of clayey nannofossil oozes and mud-clast conglomerates occurs at 130 mbsf (about 2.9-3.0 Ma: Fig. 5). At Site 836, the last emplacement of volcaniclastic turbidites (i.e., lithologic Subunit IA/IB boundary; Fig. 2) dates to about $0.4 \mathrm{Ma}$, and since then deposition has been almost wholly hemipelagic. At Site 837 , the boundary between the two contrasting sedimentation regimes probably occurred a little later, at about $760-770 \mathrm{ka}$, a date supported by shipboard paleomagnetic data.

At Site 838, the change from volcaniclastic-dominated to hemipelagic-dominated sedimentation is dated, from core data, to about 1.2 Ma. This change in the character of the sedimentary succession may possibly relate to the closest approach of the ELSC propagator to Site 838 , which occurred at about $1.65 \mathrm{Ma}$ (Parson and Hawkins and Parson et al., both in this volume). Site 838 lies less than $40 \mathrm{~km}$ distant from the western pseudofault associated with this propagator. and the site's proximity to the propagating ridge may be reflected in its tectonic and sedimentation history. At Site 839, the general sedimentary succession is the same as at the other backarc sites, with the boundary between lithologic Units I and II at about 0.9 Ma (Fig. 2). Parson et al. (this volume) discuss the range of volcanic and tectonic factors that controlled the sedimentation style in the central Lau Basin.

\section{VOLCANICLASTIC SEDIMENTS AT SITES 834-839}

Volcaniclastic material at Sites $834-839$ is mainly felsic volcanic glass. Volcaniclastic grains were found in widely varying proportions throughout the sediment recovered in the Lau Basin during Leg 135. Volcaniclastic material does not exceed $12 \%$ overall in Hole $834 \mathrm{~A}$ and $2 \%$ in Hole $835 \mathrm{~A}$ and is mainly silt sized. However, pumice fragments and hyaloclastite shards commonly reach lapilli size in the central Lau Basin (Sites 836-839), and the absolute and relative abundance of total volcaniclastic material is considerably higher,

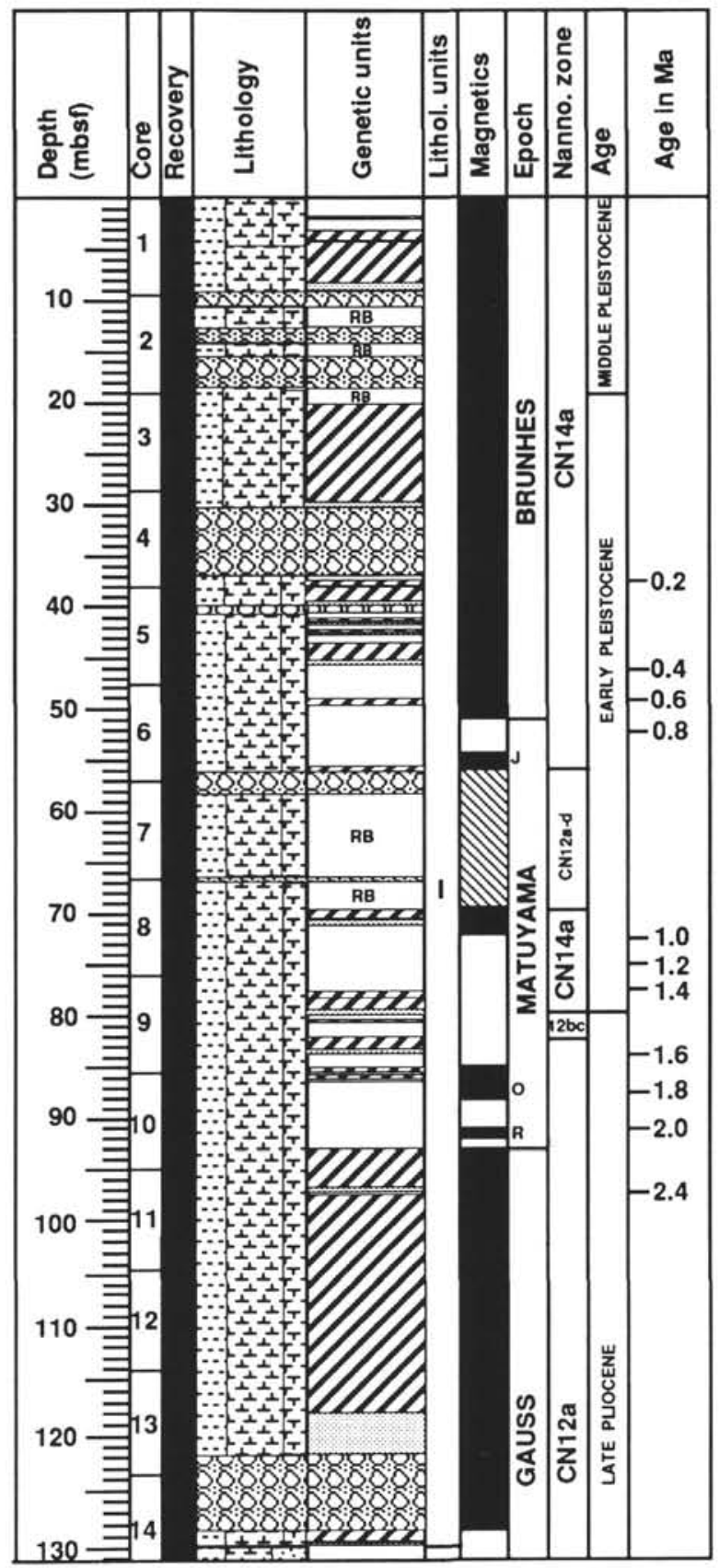

LITHOLOGY

GENETIC UNITS

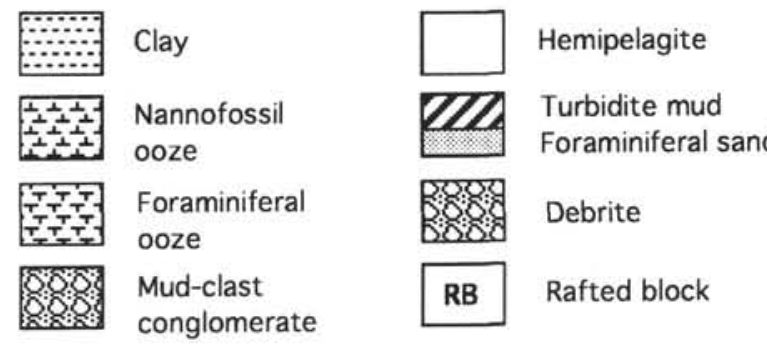

Figure 3. Genetic log through the upper Pliocene-Pleistocene sequence at Site 835 showing the occurrence of debrites, turbidites, hemipelagites, and rafted blocks (identified from micropaleontologic evidence) in the sequence with magnetostratigraphic and biostratigraphic logs alongside. Estimations of age (in Ma) were made primarily from calculations using the average hemipelagic sedimentation rate $\left(1.5 \mathrm{~cm} / \mathrm{k} . \mathrm{y} .{ }^{-1}\right)$, constrained by shipboard paleomagnetic dating. 


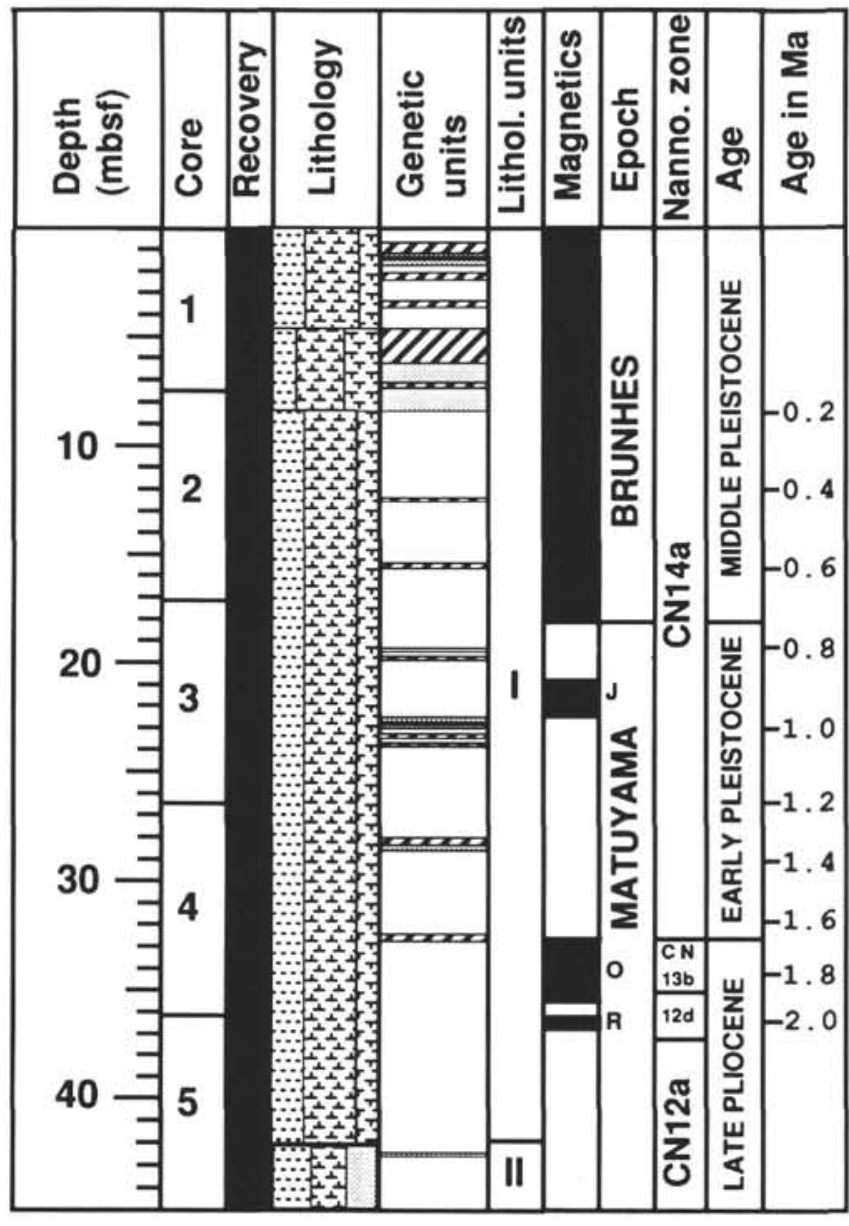

LITHOLOGY

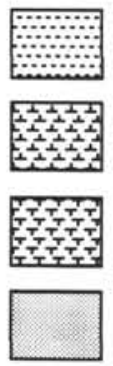

Clay

Nannofossil

ooze

GENETIC UNITS

Foraminiferal ooze

\section{Vitric sand}

Figure 4. Genetic log through the upper Pliocene-Pleistocene sequence at Site 834 showing the occurrence of clayey nannofossil ooze hemipelagites and turbidites in the sequence with magnetostratigraphic and biostratigraphic logs alongside. Estimations of age (in $\mathrm{Ma}$ ) were made primarily from calculations using the average hemipelagic sedimentation rate $\left(1.5 \mathrm{~cm} / \mathrm{k} \cdot \mathrm{y}^{-1}\right)$, constrained by shipboard paleomagnetic dating.

reaching $24 \%$ overall in Hole $836 \mathrm{~A}, 59 \%$ in Hole $837 \mathrm{~A}, 45 \%$ in Hole $838 \mathrm{~A}$, and $64 \%$ in Hole $839 \mathrm{~A}$.

Volcaniclastic sediments at the backarc sites consist of five main types:

1. Primary fallout tephras, originating from subaerial explosive eruptions. These occur mainly as discrete, conspicuous layers interbedded with hemipelagic sediments. Typically, they are only a few centimeters to several tens of centimeters in thickness. However, if sufficiently thin, they may be disrupted, perhaps totally, through bio-

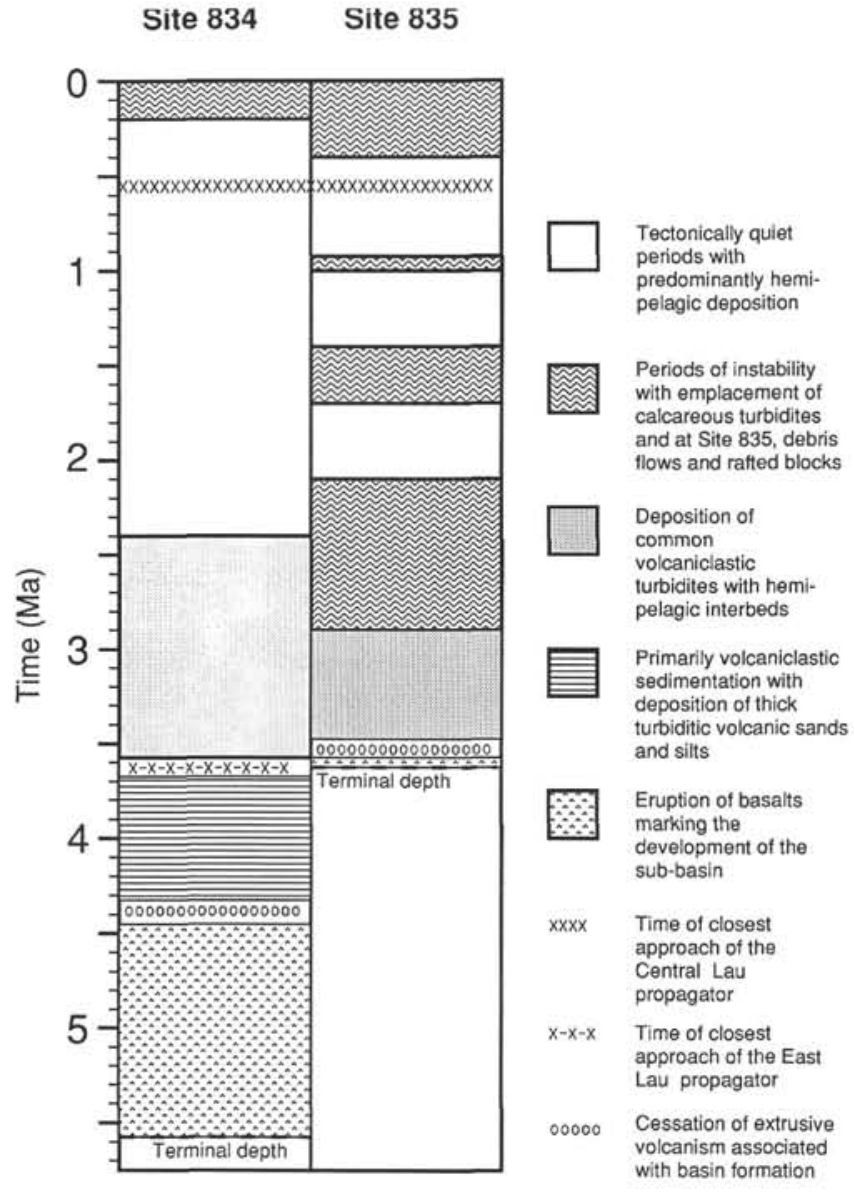

Figure 5. Summary diagram showing the geologic history of Sites 834 and 835 , particularly the episodes of instability at Site 835 and probable tectonic control of sedimentation.

turbation. The Tofua Arc provides the most likely source for many of these ash layers, although other regional volcanic centers, such as the Taupo Volcanic Zone of New Zealand (Shane and Froggatt, 1991), are known to have spread ash far into the Pacific during the Pleistocene.

2. Epiclastic deposits, whose constituent grains originally resulted from subaerial to shallow submarine eruptions on the margins of the Lau Basin (e.g., on the Tonga Ridge, Tofua Arc), occur in the volcaniclastic record, where they are redeposited by turbidity currents and other sediment gravity flows. These volcaniclastic beds are distinctive in having eroded bases and more rarely cross-bedding and laminar bedding. High concentrations of volcaniclastic material (80-100 vol\%) are commonly restricted to the basal parts of individual beds, and the upper parts commonly grade into hemipelagic sediment. Some epiclastic deposits show well developed grain-size and compositional grading and water-escape structures.

3. Subaqueous fallout and pyroclastic flow deposits resulting from explosive submarine eruptions. Increasing evidence has been collected for the occurrence of deep submarine eruptions of basaltic to rhyolitic magmas (e.g., Lonsdale and Hawkins, 1985; Gill et al., 1990; lizasa et al., 1992), especially in subduction-related settings, in which even the mafic magmas are characterized by high water contents (e.g., Muenow et al., 1990; Gill et al., 1990). However, little is known about eruption and emplacement mechanisms, dispersal patterns, and related sedimentary structures of tephras resulting from explosive deep-submarine eruptions. We assume that they produce subaqueous fallout and subaqueous pyroclastic flow deposit analogous to subaerial eruptions. Such subaqueous pyroclastic flows are likely to be difficult to distinguish from epiclastic deposits and may 
Table 1. Characteristics of clayey nannofossil ooze turbidites and hemipelagites at Site 835 in the Lau Basin.

\begin{tabular}{|c|c|c|}
\hline & Hemipelagites & Turbidites \\
\hline Color & $\begin{array}{l}\text { Reddish brown to orange } \\
\text { brown colors that show } \\
\text { subtle variation in hue } \\
\text { and chroma over short } \\
\text { segments of core. }\end{array}$ & $\begin{array}{l}\text { Reddish brown to orange brown } \\
\text { colors of consistent hue and } \\
\text { chroma, with some over long } \\
\text { intervals. }\end{array}$ \\
\hline Bioturbation & $\begin{array}{l}\text { Some light mottling } \\
\text { caused by bioturbation } \\
\text { may occur. }\end{array}$ & $\begin{array}{l}\text { Sediments appear homo- } \\
\text { geneous; bioturbation occurs } \\
\text { only near the tops of units. }\end{array}$ \\
\hline $\begin{array}{l}\text { Foraminifer } \\
\text { distribution }\end{array}$ & $\begin{array}{l}\text { Occur scattered throughout } \\
\text { sediment, which appears } \\
\text { speckled under a hand } \\
\text { lens. }\end{array}$ & $\begin{array}{l}\text { Large foraminifers rare or } \\
\text { absent, except near base of } \\
\text { units; sediment appears } \\
\text { featureless under hand lens. }\end{array}$ \\
\hline Texture & $\begin{array}{l}\text { Cut core surface } \\
\text { commonly slightly pitted. }\end{array}$ & Cut core surface usually smooth. \\
\hline $\begin{array}{l}\text { Grain-size } \\
\text { characteristics }\end{array}$ & $\begin{array}{l}\text { Grain-size spectra variable } \\
\text { over short segments of } \\
\text { core; contain variable } \\
\text { sand/coarse silt modes; } \\
\text { variable sorting values. }\end{array}$ & $\begin{array}{l}\text { Spectra highly consistent over } \\
\text { depositional intervals; } \\
\text { characterized by persistent } \\
\text { restricted coccolith modes; } \\
\text { sand/coarse silt modes absent; } \\
\text { restricted sorting values. }\end{array}$ \\
\hline $\mathrm{CaCO}_{y} / \mathrm{C}_{\text {org }}$ & $\begin{array}{l}\text { Variable over short core } \\
\text { segments. }\end{array}$ & $\begin{array}{l}\text { Consistent over depositional } \\
\text { intervals; can be several to tens } \\
\text { of meters in thickness. }\end{array}$ \\
\hline Micropaleontology & $\begin{array}{l}\text { Discoasters absent from } \\
\text { Pleistocene hemipelagites. }\end{array}$ & $\begin{array}{l}\text { May contain a variable } \\
\text { proportion of discoasters. }\end{array}$ \\
\hline Dropstones & $\begin{array}{l}\text { Weathered pumice clasts } \\
\text { common. }\end{array}$ & Absent. \\
\hline Geochemical analysis & Chemistry variable. & $\begin{array}{l}\text { Geochemical profiles show } \\
\text { consistent chemistry over } \\
\text { depositional intervals; } \\
\text { commonly clear differences in } \\
\text { element concentrations to the } \\
\text { enclosing bemipelagites. }\end{array}$ \\
\hline
\end{tabular}

grade into epiclastic deposits related to individual eruptions. Proximal and channelized facies are characterized by beds of great thickness (up to several tens of meters) and diameters of pumice clasts in the lapilli and block size range in the bases of the beds. Well-developed, water-escape structures may be common in these thick beds because of the extremely high sedimentation rates.

4. Hyaloclastites resulting from the mechanical fragmentation and spalling of chilled margins of submarine pillow tubes and sheetlava flows. These consist of predominantly blocky, angular vitric shards. These are useful as a proximity indicator for volcanic activity, although they may be redeposited locally. These hyaloclastites are predominantly in the mafic and intermediate compositional range, and are normally chemically and mineralogically homogeneous.

5. Isolated pumice dropstones, possibly derived from shallowmarine, deep-marine, or near-shore eruptions and dispersed by ocean currents. These occur throughout the Lau Basin and are especially conspicuous where they occur in hemipelagic sediments. Pumice rafts have been frequently observed in historic times in the Lau Basin (e.g., Rodda, 1986).

Bednarz and Schmincke (this volume) and Clift and Dixon (this volume) give more detailed accounts of volcaniclastic sedimentation and the volcaniclastic sediments in the Lau Basin. They also give descriptions of the analytical methods. We summarize in the following some of the most interesting results concerning the volcaniclastic sedimentation within the backarc basin.

\section{Proximal Nature of the Volcaniclastic Deposits}

The coarse grain size and the sedimentary structures of the vitric turbidites and sediment gravity-flow deposits that make up the bulk of the lower volcaniclastic-dominated sequence indicate that sedimentation during the initial stages of sub-basin formation was essentially a localized process. Further evidence for the proximal nature of the volcaniclastic deposits comes from electron microscope studies of individual glass grains (Bednarz and Schmincke, this volume), which usually show delicate needle-like shard morphologies, whose survival is incompatible with long-distance transport. Furthermore, the almost exclusively fresh character of the sand-sized vitric grains points to active volcanoes as the principle sediment-producing agents throughout the backarc basin. However, given that most of the sediment appears to have been deposited relatively close to its origin (Clift and Dixon, this volume), the volcano in each case cannot have been part of the Tofua Arc. In addition, evidence from Site 840 on the Tonga Platform suggests that activity on the volcanic arc adjacent to the basin underwent a hiatus during the initial stages of basin rifting and thus would not have been available as a sediment source (Clift and Dixon, this volume). The sedimentary and topographic evidence point to a Pliocene Lau Basin characterized by proximal sedimentation around intrabasinal seamount volcanoes.

The geochemistry of individual sediment grains from the sediments of the backarc basin allows the model of localized sedimentary sources to be supported and extended. Clift and Dixon (this volume) analyzed samples for a suite of 10 major elements. Of these grains, a selected subset of low-silica volcanic glasses was analyzed for a suite of 20 trace and rare earth elements. Low-silica grains were selected to minimize the effect of fractional crystallization. Where possible, aphyric glasses were chosen in preference to phyric glasses, which must have suffered some effect of fractional crystallization.

The principle aim of this probe work was to determine the dominant types of volcanic glass grains reworked into the basin and therefore the nature of intrabasinal seamount volcanism. Figure 6 shows the variability in total silica values for volcanic glass grains from Sites 834 through 839 . Glass variability does not seem to change from the base to the top of the sediment column at any site. However, three different types of patterns are recognizable among individual sites. Sites 834 and 835 are seen to display a full array of silica values that range from basaltic andesite to rhyolite. In contrast, Sites $837-839$ show a strongly bimodal pattern, with basaltic andesites and rhyolites dominating. Standing by itself, Site 836 has a unimodal glass assemblage, comprising basaltic andesite glass alone. Further discrimination is possible using Peccerillo and Taylor's (1976) $\mathrm{K}_{2} \mathrm{O}$ /silica diagram (Fig. 7). This diagram shows that the vast majority of glass grains from throughout the basin are of the low-K type, in agreement with the work of Cawood (1991) from the Tonga forearc. However, a small number of grains from Sites 834 and 835 are of medium- and high-K types. This reinforces the subdivision made on the basis of silica contents alone, although no discrimination is possible between Sites 837-839 and Site 836 on the basis of the $\mathrm{K}$ content.

The chemical subdivision of the sites described above reflects the position of each site within the basin. Sites 834 and 835 lie some distance from the other sites; from the sedimentary evidence, they would be expected to have a different source. This prediction is supported by the probe work. Similarly, although Site 836 lies close to Sites $837-839$, a distinctive geochemical grouping may be expected. This is because Site 836 is considered, on the basis of its age, as well as on geophysical and morphological characteristics (Parson, Hawkins. Allan, et al., 1992), to lie within crust generated along the ELSC. This contrasts with the crust of the other sites, which comprises volcanically floored basins within an extended volcanic arc crust.

An interesting comparison can be drawn between the chemistry of the volcaniclastic rocks within the basin and the island arc itself, as recorded at Site 840 . Analysis of glasses from Site 840 shows that the volcanic history is broken neatly into pre-and postrifting episodes, the former characterized by a wide spectrum of silica values and the latter by a bimodal distribution (Clift and Dixon, this volume). As such. Sites 834 and 835 are clearly associated with the prerift volcanism, whereas Sites $837-839$ are more readily correlated with the later history. The same comparison can be drawn with the alkali contents, because the prerift history is marked by a spectrum of high- to low-K volcanics, contrasting with the exclusively low-K postrift history. The 
Sites 834 and 835

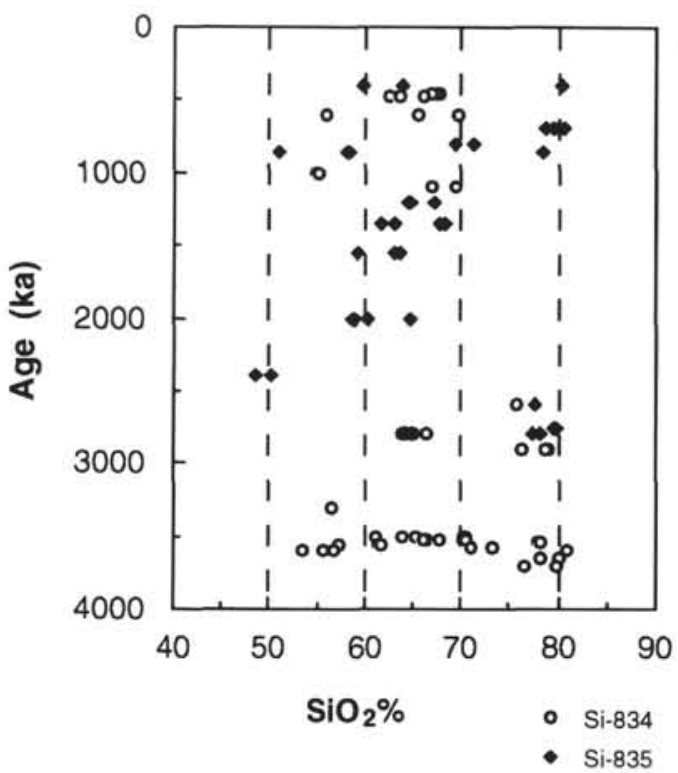

Sites 836 and 837

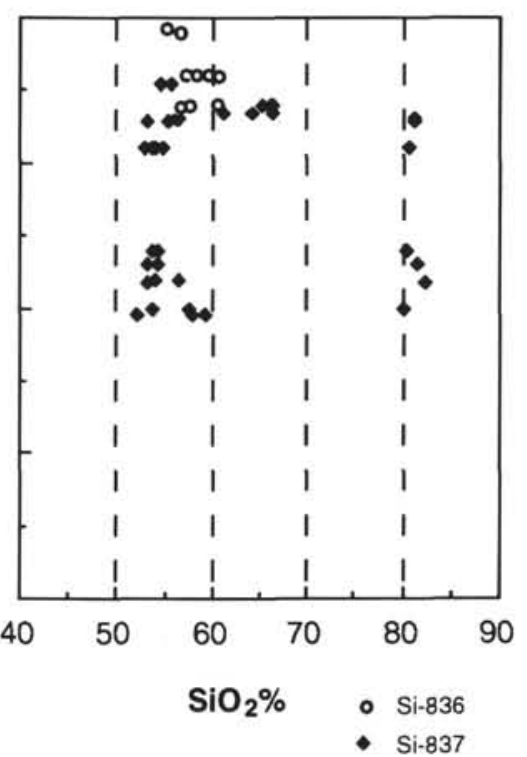

Sites 838 and 839

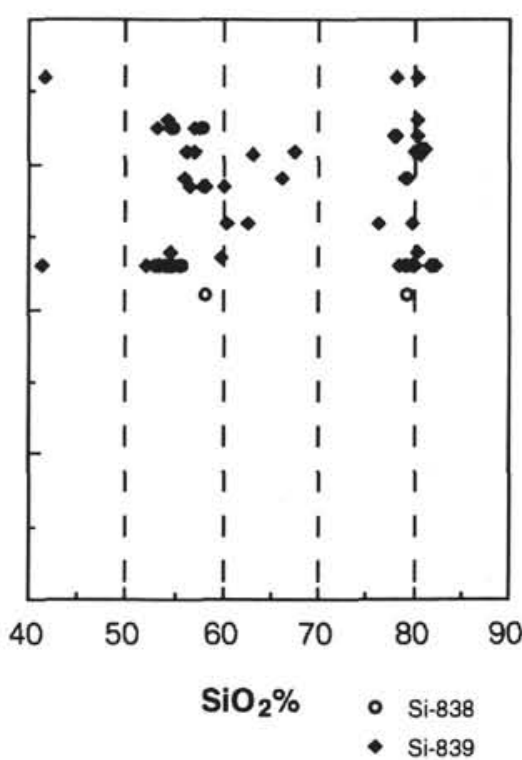

Figure 6. Diagram showing the variation in total silica contents of volcanic glass grains with age for Sites $834-839$ (Lau backarc basin). Silica contents plotted are taken after correction of the major elements to $100 \%$.
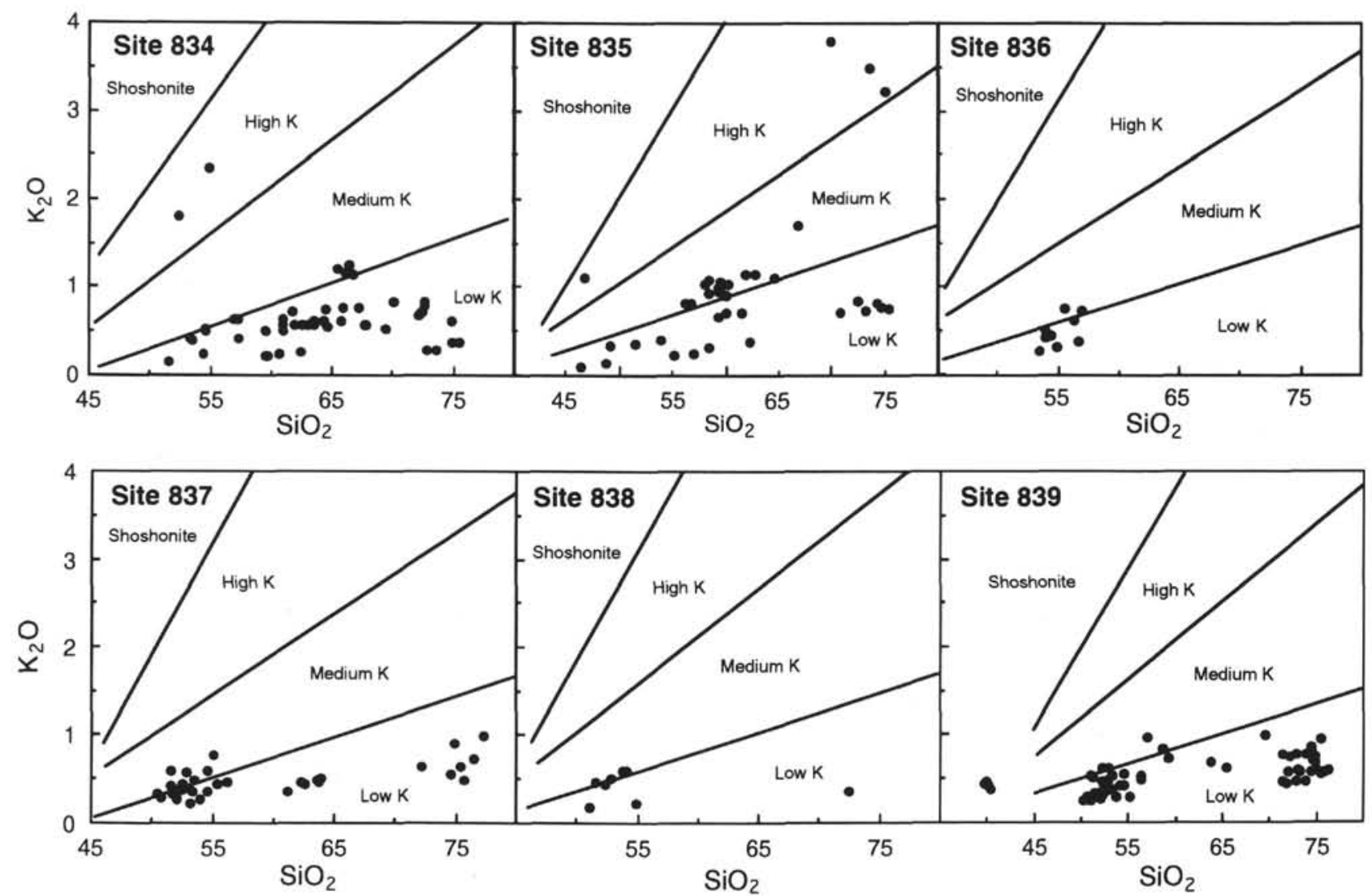

Figure 7. Compositional plots of $\mathrm{K}_{2} \mathrm{O}$ vs. $\mathrm{SiO}_{2}$ for detrital glass from Sites 834 through 839 , showing the dominance of low-K tholeiite, although with a greater spread into high-K compositions at Sites 834 and 835. Compositional fields are from Peccerillo and Taylor (1976). 
differences in major element chemistry between the two groups of sites (i.e., Sites 834 and 835 and Sites 837-839) show their separate sediment provenance. However, because there is an age progression to the formation of backarc sub-basins, the major element data also have implications for the history of backarc magmatism. The probe data show that the volcanoes that produced the volcaniclastic detritus underwent a change in their chemistry, not at the point of basin rifting, as suggested by the data from Site 840 , but between the formation of Sites 835 and 837 (i.e., between 3.6 and $2.1 \mathrm{Ma}$ ), instead.

\section{Chemical Composition of Volcaniclastic Deposits and Evolution of Volcanism}

\section{Lau Ridge}

One epiclastic unit, recovered from a depth of $69.56 \mathrm{mbsf}$ in Hole 834 A with a thickness of 1.35 m (termed "Bed BA"; see Parson, Hawkins, Allan, et al., p. 108), differs from the other volcaniclastic beds found in the Lau Basin during Leg 135 in that

1. its vitric shards and bulk rocks are the only calc-alkaline to shoshonitic basalts $\left(\mathrm{K}_{2} \mathrm{O}\right.$ at about $\left.1.8 \mathrm{wt} \%\right)$ found at Sites 834-839;

2 . it has a unique phenocryst assemblage of plagioclase, hypersthene, hornblende, biotite, and opaque minerals;

3 . it has the coarsest volcaniclastic grain size (median $=2.13-$ $3.20 \phi ; 0.11-0.23 \mathrm{~mm}$ ) found at Sites 834 and 835 ; and

4. high vesicularity of the relatively mafic glass shards is present;

5. it contains neritic foraminifers.

Bednarz and Schmincke (this volume) identified this bed as derived from eruptions on the Lau Ridge and estimated its age at $3.3 \mathrm{Ma}$. Bed BA correlates stratigraphically and compositionally with lavas found on the neighboring Lau Ridge islands, Moce and Olorua (belonging to the Korobasaga Volcanic Group), which have an estimated age ranging from 2.5 to $4.5 \mathrm{Ma}$ (Cole et al., 1985). Although the whole Korobasaga Group shows a wide range of chemical composition, lavas from the Moce and Olorua islands are almost identical in composition to those of Bed BA. Bed BA, therefore, is interpreted as resulting directly from the eruption and deposition of tephra derived from explosive, subaerial to shallow, submarine volcanism on Moce and Olorua islands.

No other volcaniclastic sediments were recovered during Leg 135 that match the chemical compositions from the Lau Ridge, including the Mago Volcanic Group ( $<2.5$ m.y.).

From the relative scarcity of volcaniclastic input to the basins containing Sites 834 and 835 , it seems unlikely that widespread and/or voluminous volcanism postdating the initial opening of the Lau Basin occurred on the Lau Ridge. This holds true especially for the eruption of highly explosive, differentiated magmas.

\section{Lau Basin (Volcanism at Spreading Centers)}

Constructive margin volcanism, which also occurs in backarc basins, is typically characterized by intrusion and deep-sea effusion of mainly mafic magmas. The formation and deposition of volcaniclastic material, therefore, is dominated by nonexplosive processes such as the spalling of the chilled margins of sheet flows and pillow lavas. The effectiveness and likelihood of fragmentation in this environment is dependent mainly on the volatile content of the magma and on the seafloor pressure (e.g., Kokelaar, 1986). In the deep-sea environment, in contrast to the emergent stages of growing seamounts, a large ambient pressure normally prohibits the formation of voluminous volcaniclastics because thin, insulating vapor films stabilize the chilled, glassy margins of active lava flows. This effect is consistent with the overall scarcity of interlava volcaniclastic rocks within the basement of the Lau Basin (Parson, Hawkins, Allan, et al., 1992) and the scarcity of post-basement volcaniclastic rocks that can be attributed directly to a source at one of the constructive margins of the Lau Basin (Bednarz and Schmincke, this volume). Post-basement volcaniclastics have been identified only at Site 836 . The young volcanic basement at this location is only about $0.64-0.8 \mathrm{Ma}$ old and is covered by only $20 \mathrm{~m}$ of sediments. These sediments contain 43 layers rich in volcaniclastic material that make up about $50 \%$ in the lower half of the sedimentary section.

These sediments deposited between 0.6 and $0.5 \mathrm{Ma}$ are composed predominantly of platy, blocky, and angular vitric shards. These shards have limited compositional range, with 54.3 to $58.1 \mathrm{wt} \% \mathrm{SiO}_{2}$ (Bednarz and Schmincke, this volume). Low $\mathrm{Ba} / \mathrm{Zr}$ ratios of $0.9-1.4$ are similar to some lavas from the modern Lau Basin (e.g., Sunkel, 1990).

Five to seven layers, comprising mainly basaltic and basaltic andesitic clasts, occur per meter of core in this depth interval, corresponding to a depositional rate of about 13 layers per 50 k.y. Predominantly blocky shapes, relative low vesicularity, and abundant trachytic textures support the origin of these particles as hyaloclastites from nearby spreading-related volcanism. The chemical similarity of these hyaloclastites to lavas from presently active spreading centers in the Lau Basin, including the predominance of intermediate compositions and the large maximum and average grain sizes also support this interpretation.

\section{Lau Basin (Off-ridge Volcanism)}

Among the most surprising discoveries of Leg 135 was the recovery of abundant, almost pure, low-K, high-silica rhyolitic vitric shard-rich volcaniclastic deposits. These deposits are commonly several tens of meters thick at Sites 837, 838, and 839 in the central Lau Basin and are chemically homogeneous in terms of characteristic trace element ratios (Bednarz and Schmincke, this volume). Among these, one unit from Hole 837A and one unit from Hole 839A, with a thickness of 25.2 and $43.7 \mathrm{~m}$, respectively, are particularly noteworthy. Both deposits consist almost totally of volcaniclastic material with little or no admixtures of nonvolcanic detritus. Both units are identical in bulk chemical and mineralogical composition. The units are thickly bedded to thickly laminated at their bases with bulk andesitic composition (61.1-66.6 wt $\% \mathrm{SiO}_{2}$ and $0.51-0.76 \mathrm{wt} \% \mathrm{~K}_{2} \mathrm{O}$ ). Clasts comprise varying proportions of predominantly colorless, highly vesicular pumice, with lesser amounts of pale brown, blocky, and angular shards of low to medium vesicularity. The maximum diameter of pumice lapilli is $30 \mathrm{~mm}$ at the base of the unit in Hole 839A and $5 \mathrm{~mm}$ at the base of the corresponding unit in Hole 837A. Plagioclase, hypersthene, clinopyroxene, and opaque minerals reach up to $10 \mathrm{vol} \%$ locally. At least the upper twothirds of both flows has a rhyolitic bulk composition (69.6-74.0 wt\% $\mathrm{SiO}_{2}$ and $0.88-1.12 \mathrm{wt} \% \mathrm{~K}_{2} \mathrm{O}$ ). Median grain sizes of the vitric shards are $28-30 \mu \mathrm{m}$ in the upper parts of the unit in Hole $837 \mathrm{~A}$ and $40 \mu \mathrm{m}$ in Hole 839A. Igneous minerals are rare. Trace element ratios such as $\mathrm{Zr} / \mathrm{Y}(2.06$ to 2.38$)$ and $\mathrm{Ba} / \mathrm{Zr}$ (3.57 to 3.99$)$ show only little variation.

Although Holes $837 \mathrm{~A}$ and $839 \mathrm{~A}$ are $>50 \mathrm{~km}$ apart, these two units can be correlated, based on geochemical, sedimentological, and volcanological criteria and interpreted as submarine pyroclastic flow units erupted from one single, paroxysmal, deep-submarine eruption (Bednarz and Schmincke, this volume). The observed bulk-chemical variations are interpreted as the result of partial discharge of a chemically zoned magma chamber. The flanks of a seamount located at about $20^{\circ} 40^{\prime} \mathrm{S}, 177^{\circ} 10^{\prime} \mathrm{E}$, is postulated as the eruptive site by Bednarz and Schmincke (this volume). This view is based on consideration of bathymetric constraints on potential pathways for mass flows to reach Sites 837 and 839 and is supported by geochemical data (Bednarz and Schmincke, this volume). From this seamount, clear pathways existed to the north (Hole 837A) and south (Hole 839A). The greater distance to Hole $837 \mathrm{~A}$ in comparison to Hole $839 \mathrm{~A}$ is consistent with the greater thicknesses and coarser grain size of the deposits seen at Hole 839A.

There are a number of arguments for many other volcaniclastic deposits found during Leg 135 , especially those recovered in Holes $837 \mathrm{~A}$ to $839 \mathrm{~A}$, as having an origin from explosive, deep-submarine 
eruptions. These include the abundance of thick and coarse-grained volcaniclastic beds, extremely high sedimentation rates (e.g., 882 $\mathrm{mm} / \mathrm{k}$.y. below $100 \mathrm{mbsf}$ in Hole $838 \mathrm{~A}$ ), and geochemical similarity to lavas from the Lau Basin basement, for example, in terms of low ratios of large-ion-lithophile elements (LILEs) over high-fieldstrength elements (HFSEs). However, it is difficult to ascertain how representative this inferred abundance and volume of deep-submarine, explosive, and silicic volcanism is for the whole of the Lau Basin or even the western Lau Basin. Because of technical restrictions, ODP sampling is strongly biased toward sediment-filled basins in which the deposition of volcaniclastic sediments by sediment gravity flows and/or submarine pyroclastic flows is high and there is the potential for the loss of the thinner fallout tephras. These latter deposits may be as important and as voluminous, when one considers the large areas that fine-grained ashes from explosive eruptions can cover (e.g., Williams and Goles, 1968; Walker, 1980). However, in the cores recovered from the Lau Basin during Leg 135, volcaniclastic sediments resulting from deep-submarine explosive eruptions have a much higher volume than volcaniclastic deposits from any other source.

\section{Tofua Arc}

Abundant ash layers and volcaniclastic deposits, all younger than $840 \mathrm{ka}$, as recovered through dredging and coring during extensive campaigns by Sonne in the Lau Basin, have been interpreted as fallout ashes and turbidites resulting from the remobilization of fallout ashes, originally derived from the Tofua Arc (e.g., von Rad and Mühe, 1990). In the Lau Basin, the backarc sites with most volcaniclastic layers less than 1 m.y. old, are found in the central Lau Basin, with 36, 16, and 11 layers occurring in Holes $837 \mathrm{~A}, 838 \mathrm{~A}$, and $839 \mathrm{~A}$, respectively. In Holes $834 \mathrm{~A}$ and $835 \mathrm{~A}$, which are located $50 \mathrm{~km}$ to the west, three and two volcaniclastic layers have been identified, respectively, as younger than $1 \mathrm{Ma}$. Only a few of these could be positively identified as primary fallout deposits during shipboard analysis (Parsons, Hawkins, Allan, et al., 1992). Eleven ash layers, less than 1 Ma old, which have characteristics of primary fallout deposits, were analyzed by Bednarz and Schmincke (this volume). These are basaltic to rhyolitic in composition and most are characterized by a distinct "arc" signature, for example, $\mathrm{Ba} / \mathrm{Zr}$ ratios $>4$ and up to 10 . These LILE/ HFSE ratios, which are significantly higher than in most other volcaniclastics of the Lau Basin, are similar to most samples of the younger sediments in the cores collected during the Sonne cruises (U. von Rad, unpubl. data). It seems likely that these layers have an origin from the active island arc, and this is consistent with the increasing abundance of layers in those sites that lie closer to the active arc.

\section{Petrogenetic History of the Volcanics Deduced from Trace and Rare-earth Studies}

An attempt to deduce the petrogenetic history of the volcanic rocks at each site, using trace and rare-earth elements, was made by analyzing a series of low-silica glass grains $\left(\mathrm{SiO}_{2}<55 \%\right)$. To examine a multitude of elements at one time, multielement spider diagrams (e.g., Pearce, 1983) were constructed and normalized against NMORB (values of Sun and McDonough, 1989). In almost all cases, these plots (Fig. 8) showed a strong subduction related character. The enrichment of LILEs above NMORB values is coupled with a relative depletion in $\mathrm{Nb}$ below the level of the other HFSE and rare-earth elements (REEs). The majority of the water-immobile elements, plotting to the right of $\mathrm{Nb}$ on the spider diagram, are seen to plot as a straight line parallel to NMORB, but displaced both higher and lower than NMORB. This displacement may reflect the effects of fractional crystallization. An important exception to this general pattern is seen at Site 834. Although glasses analyzed from the lower part of the sediment section (i.e., those of Pliocene age) show the regular subduction pattern, those from higher in the section (e.g., Sample 135834A-3H-1, 72 cm; Fig. 9) have a different pattern. The Nb depletion and LILE enrichment are still features of the spider diagrams. However, the intermediate incompatible elements also show a depletion (Fig. 9), in a style reminiscent of boninites (e.g., Simonian, 1975).

The form of the incompatible elements on the spider diagrams shown in Figures 8 and 9 represents the interplay of the REEs with the HFSEs. The generally depleted nature of the incompatible HFSEs produces an apparent $\mathrm{Nb}$ deficiency, compared with a variably enriched REE suite. At Site 840 (Clift and Dixon, this volume), a trend to increasing HFSE depletion is seen up until the time of rifting within the Lau Basin. After rifting, HFSE depletion at Sites 834-839 appears to vary abruptly with time and can be considered in isolation through use of the ratio $\mathrm{Zr} / \mathrm{Nb}$. Because $\mathrm{Zr}$ is more compatible in mantle phases than $\mathrm{Nb}$, their ratio defines the degree of HFSE depletion. Figure 10 shows the range of values for $\mathrm{Zr} / \mathrm{Nb}$ vs. time for all backarc sites. As at Site 840, the range is large and no obvious pattern emerges to the evolution in HFSE depletion in Lau Basin sands with time. A similar situation is seen for the REEs (Fig. 11), as represented by $\mathrm{Ce} / \mathrm{Ho}$ (light rare-earth element/heavy rare-earth element [LREE/HREE]).

The trace and rare-earth element analyses show that the volcanoes that were the source of the sediments found in the Lau Basin were strongly influenced by a subducting slab. The distinctive nature of the spider diagrams obtained from basaltic andesite glasses in the Pleistocene at Site 834 suggests that this site has a different source than the rest of the basin at this time. In terms of their HFSE and REE characteristics, Lau Basin volcanic glass grains show a variety of degrees of depletion, with no obvious trend in time or spatially across the basin. Previous workers (e.g., Pearce, 1983) and new supporting data from Site 840 (Clift and Dixon, this volume) indicate that the two elemental groups are decoupled during petrogenesis. The HFSEs are controlled by melting in the mantle wedge, whereas the REEs are controlled by the flux of LREEs from the dewatering subducting slab. If this is true, then the Lau Basin glasses suggest that the mantle under the Lau Basin has been heterogeneously depleted in HFSEs and has been subject to a variable slab flux during the period of rifting. Before Lau Basin rifting, the subarc mantle, as recorded at Site 840 , shows a trend to increasing HFSE depletion. The data from Sites 834-839, therefore, indicate that basin rifting drew in fresh mantle sources under the arc, which were mixed with the depleted mantle material in a nonuniform manner.

\section{GEOCHEMISTRY OF HYDROTHERMAL SEDIMENTS AND MANGANESE CRUSTS RECOVERED FROM BACKARC SITES}

Previous studies of the geochemistry of Lau Basin sediments have been based mainly on surface and short-core sediment samples and are thus focused on the regional as opposed to temporal variations in geochemical composition. These studies (e.g., Hodkinson et al., 1986; Moorby et al., 1986; Walter et al., 1990; Reich, 1990; Hodkinson and Cronan, 1991) have shown that the sediment bulk geochemistry reflects two major sediment components-biogenic carbonate and volcaniclastic detritus - with a widely dispersed hydrothermal oxide phase superimposed upon these components. In addition, a hydrothermal sulfide and/or weathered sulfide phase in the sediments has been shown to be locally significant adjacent to the active neovolcanic zones (Hodkinson and Cronan, 1991).

One of the aims of Leg 135 was to recover complete sediment columns down to basement from different localities within the basin so as to assess both the nature of the hydrothermal component and the long-term variability in its input to the sediments and to relate this to the tectonic evolution of the basin.

To determine precisely the nature of the hydrothermal input to the sediments, to quantify it, and to assess its temporal variability at the six ODP backarc sites, 872 samples were analyzed by inductively coupled plasma atomic emission spectroscopy (ICPAES). Results show (see Hodkinson and Cronan, this volume) that the hydrothermal 


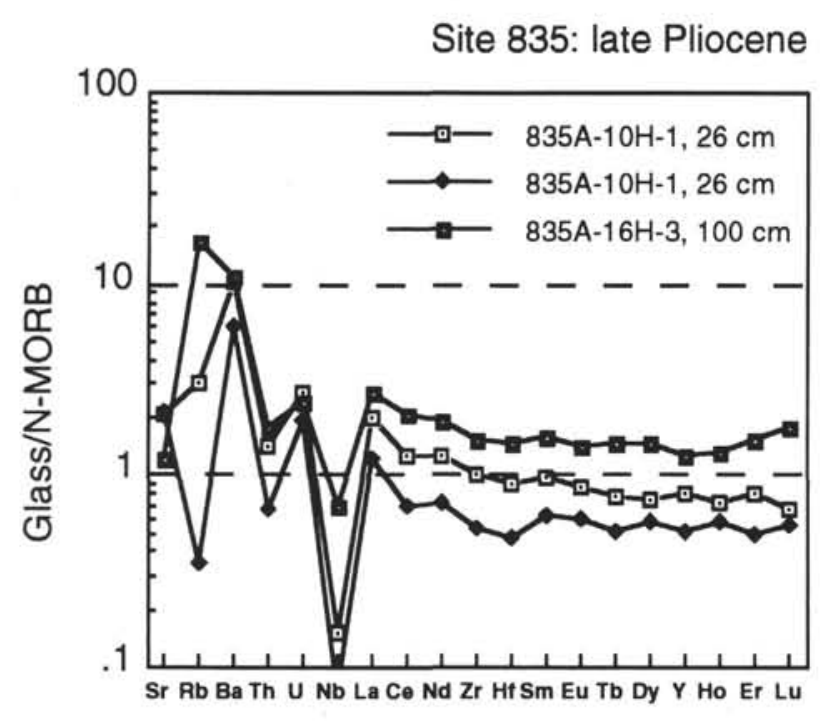

Site 835: early Pleistocene

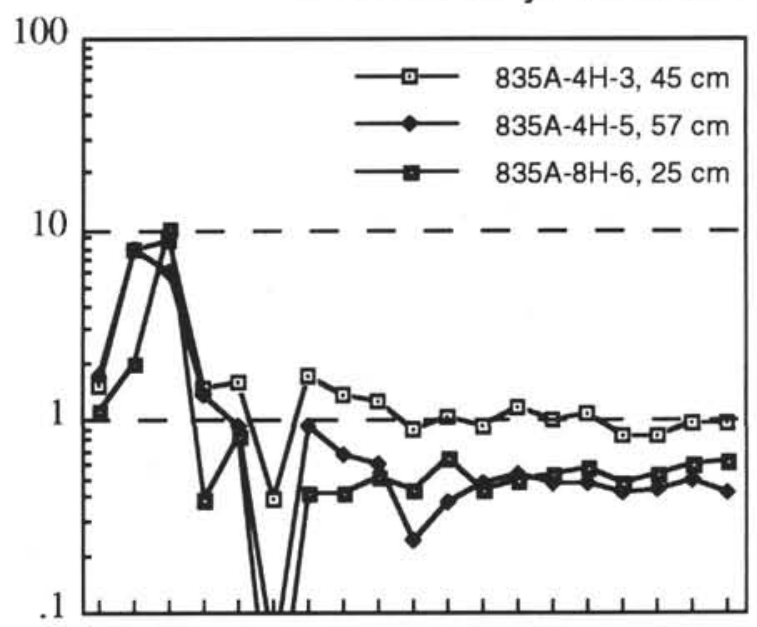

Sr Rb Ba Th U Nb La Ce Nd Zr HrSm Eu Tb Dy Y Ho Er Lu

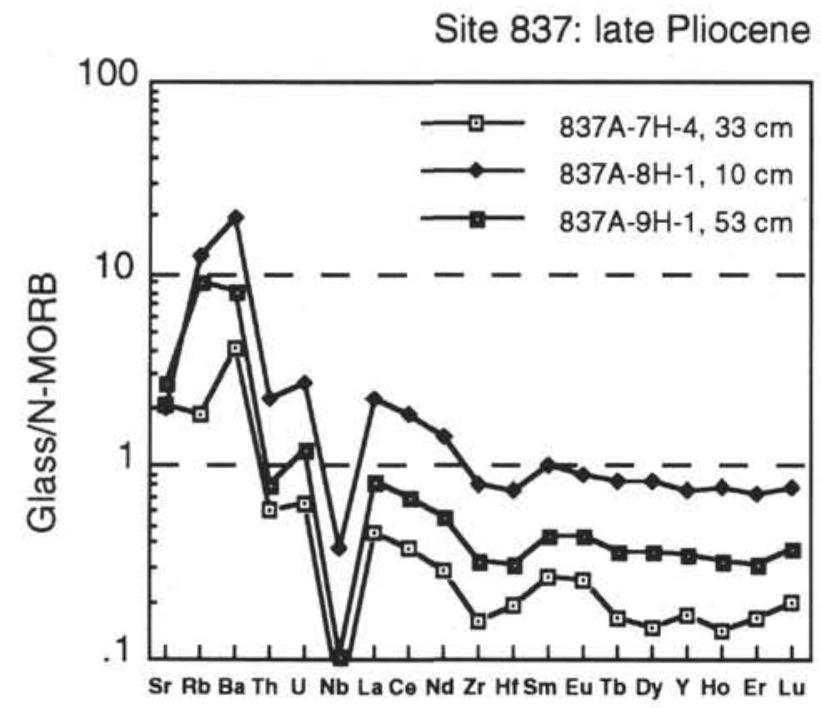

Site 837: early to middle Pleistocene
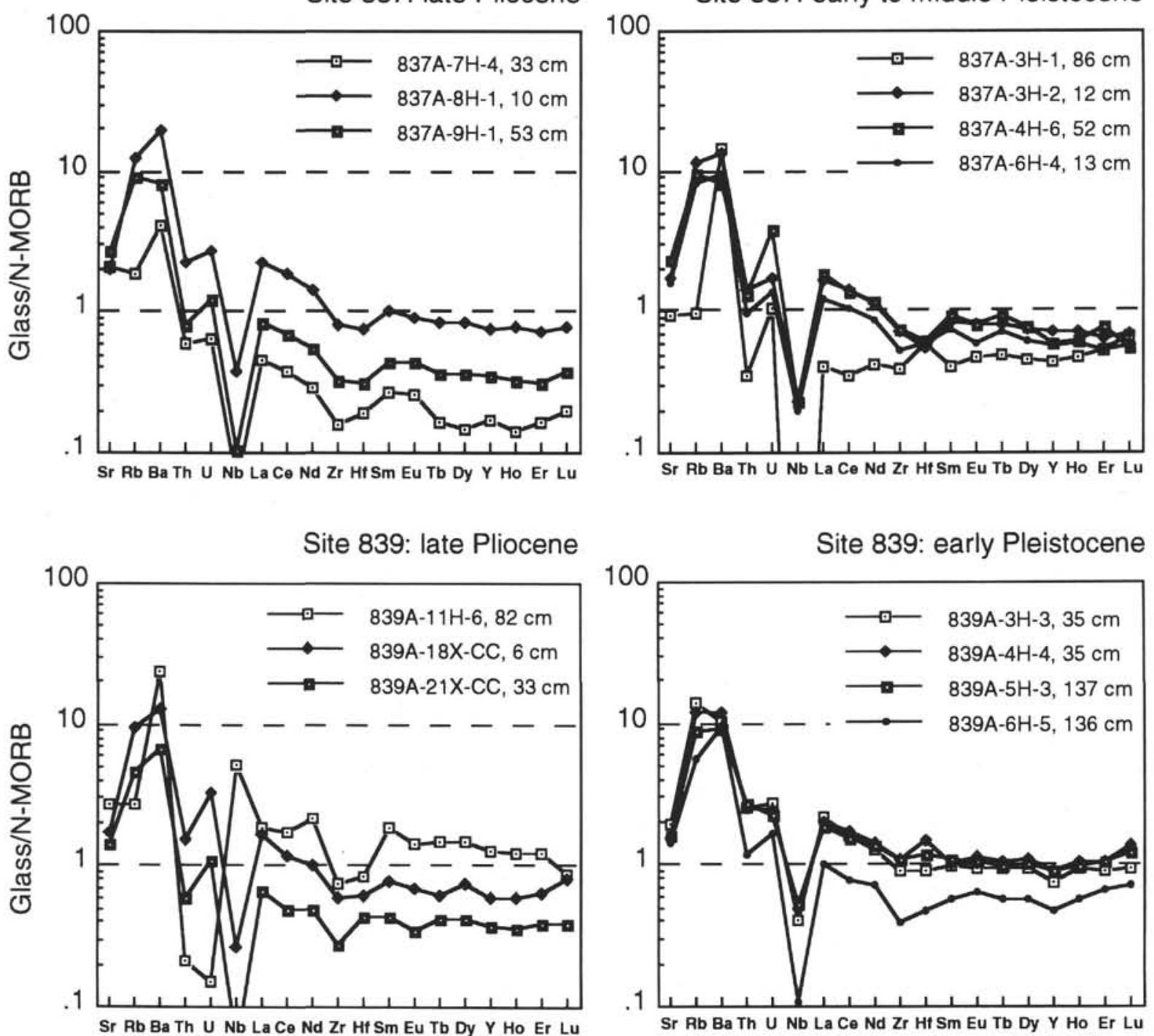

Figure 8. Spider diagrams of basaltic glass grains from Sites 835,837 , and 839 showing the flat immobile-element trend and subduction zone overprint. Elements are normalized to NMORB and values used are from Sun and McDonough (1989). Elements are arranged with water-mobile elements on the left and water-immobile elements on the right. Compatibility in mantle phases increases away from $\mathrm{Nb}$ on either side. Relative $\mathrm{Nb}$ depletion and enrichment of water-mobile LILEs is typical of island arc tholeitic volcanism. 

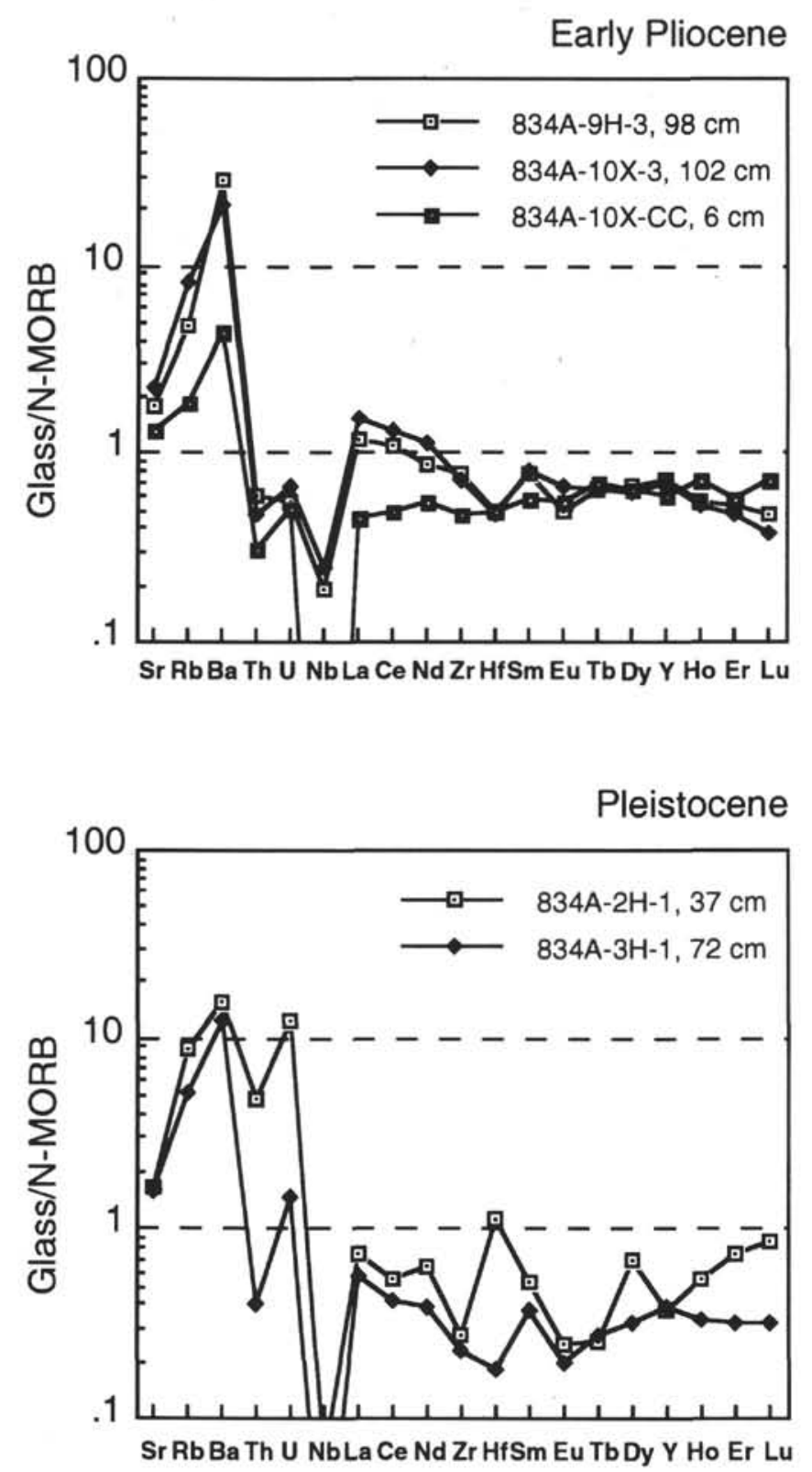

Figure 9. Spider diagrams of basaltic glass grains from Site 834 showing the change in glass composition since initial arc rifting. The source of Pleistocene glass debris does not correlate with the other Lau Basin sites or with Site 840 .

phase of the sediments is composed of $\mathrm{Mn}$ and $\mathrm{Fe}$ oxides with the associated coprecipitated elements $\mathrm{V}, \mathrm{Co}, \mathrm{Ni}, \mathrm{Cu}, \mathrm{Zn}, \mathrm{Pb}$ and $\mathrm{P}$, typical of hydrothermal plume fallout both in the Lau Basin surface sediments (Hodkinson and Cronan, 1991) and from mid-ocean spreading environments such as the East Pacific Rise (Lyle et al., 1986; Barrett et al., 1987). In contrast to the study of the Lau Basin surface sediments (Hodkinson and Cronan, 1991), no evidence of a sulfide/weathered sulfide hydrothermal phase, shown to be locally associated with the neovolcanic spreading complexes, is seen in the sediments studied here. The absence of such a phase would suggest that none of the backarc sites studied were immediately adjacent to a hydrothermal discharge zone at the time of sediment accumulation.

Sites 834 and 835 contain significantly higher maximum hydrothermal inputs compared with the other backarc sites or surface sediments (Hodkinson and Cronan, 1991; Walter et al., 1990). Ex-

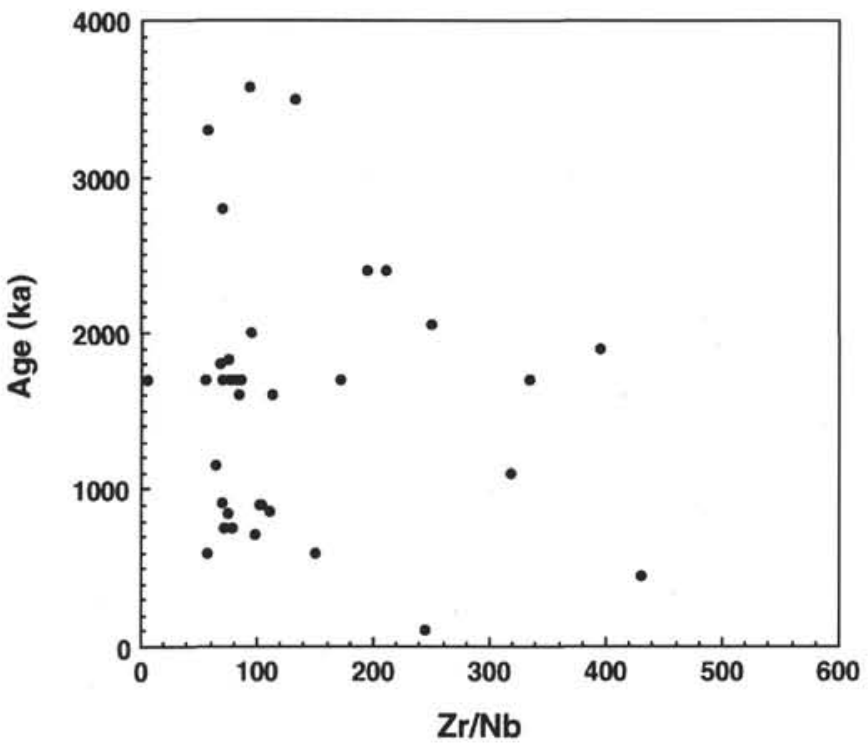

Figure 10. Diagram showing the variability of $\mathrm{Zr} / \mathrm{Nb}$ in low-silica glasses with time throughout the Lau Basin.

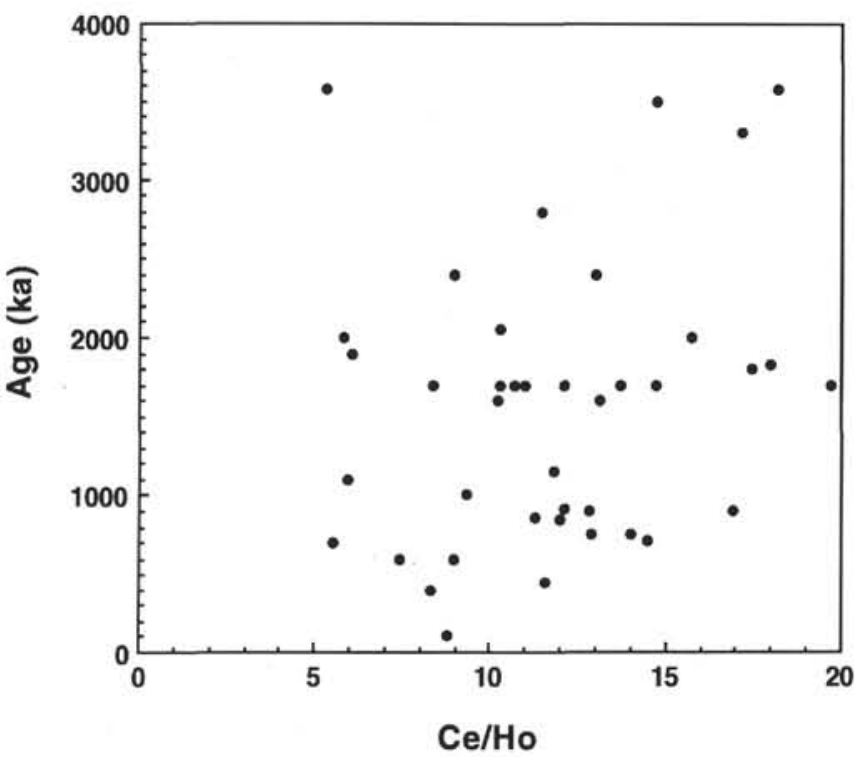

Figure 11. Diagram showing the variability of $\mathrm{Ce} / \mathrm{Ho}$ in low-silica glasses with time throughout the Lau Basin.

pressed as a combined $\mathrm{Fe}$ and $\mathrm{Mn}$ oxide content, the maximum nondetrital carbonate free ferromanganese oxide contents reach $45.4 \%$ and $35.9 \%$ at Sites 834 and 835 , respectively.

In terms of downhole variability in the hydrothermal oxide component, all backarc sites, with the possible exception of Site 836, show a similar trend. A period of increased hydrothermal input occurs at depth at all sites, whereas above and below this interval of high hydrothermal input a general trend of decreasing hydrothermal input is present. Such a trend indicates that the maximum hydrothermal input to sediments within the basin did not occur immediately after basement crust formation but rather at a later stage of basin history. 
This is in marked contrast to the trend seen at mid-ocean spreading centers (e.g., the East Pacific Rise; Lyle et al., 1986; Barrett et al., 1987), where a general uphole decrease away from basement results from the increased distance of the site with respect to the hydrothermal plume source caused by crustal spreading.

Parson and Hawkins (this volume) proposed a model of basin evolution in which crust in the western part of the basin formed as a result of extensional rifting and localized arc magmatism before the onset of "true" backarc spreading. This was accomplished by means of propagation of the ELSC into this attenuated crust, followed subsequently by propagation of the Central Lau Spreading Center (CLSC) into ELSC-generated crust. Based on this model of basin evolution, the general trend of a high hydrothermal input some distance above basement followed by a decline can be accounted for by the southward propagation of the ELSC past the latitudes of the backarc sites (all of which, with the exception of Site 836 , are postulated to be located on pre-ELSC generated crust). This would have resulted in an increase in the hydrothermal flux to the sediments as the spreading ridge approached, followed by a decrease in the flux because of subsequent crustal spreading at the newly formed spreading axis. The timing of the period of maximum hydrothermal flux to the sediments shows that the period of maximum input does not occur at the time of passage of the propagating ridge tip but rather at some period after its passage. Estimates, although not definitive, suggest this delay or "lag" is some 0.4 m.y. in the case of Sites 834 and 835 and probably some 0.6 m.y. in the case of Sites 837 to 839 (see Hodkinson and Cronan, this volume). Such a lag may occur because a period of time may be required for a hydrothermal system associated with the newly formed spreading axis to become fully established and record its maximum input to the sedimentary sequence. Such a model would not be at variance with present-day observations of the Valu Fa Ridge and the CLSC, where the sites of most intense hydrothermal discharge occur not at the propagating tips but rather at some distance behind them (see Hodkinson and Cronan, this volume). Subsequent propagation of the CLSC into preexisting ELSC-generated crust may also be reflected in the sedimentary hydrothermal record at Sites 834 and 835, although such peaks are not definitive.

Unlike the other backarc sites, however, Site 836 is located on crust generated at the ELSC post-ridge propagation and would therefore be expected to show a hydrothermal record more analogous to that of the EPR. Although not definitive, the hydrothermal record at Site 836 is compatible with this.

Superimposed on the overall downhole trends at all sites are short-term periods of both enhanced and reduced hydrothermal input. Such periods probably reflect, in part, temporal variability in the discharge of hydrothermal systems; however, they probably also reflect periods of reorganization of the spreading complexes, including an intermittent or stepwise propagation of the spreading complexes, as proposed by Parson and Hawkins (this volume). Similarly, variations in the rate of change of hydrothermal flux to the sediments are most likely a reflection of variations in crustal spreading rates, also identified by Parson and Hawkins (this volume).

\section{Hydrothermal Manganese Crusts}

In addition to the hydrothermal ferromanganese oxide component of the sediments, hydrothermal minerals in the form of small manganese crust fragments were recovered at Site 835 (in Sections 135 $835 \mathrm{~A}-17 \mathrm{H}-1,93-100 \mathrm{~cm}$, to $-17 \mathrm{H}-\mathrm{CC}, 0-32 \mathrm{~cm}$ ) and at Site 838 (in Sections 135-838A-6H-6, 78-80 cm, -6H-7, 4-6 cm, $-7 \mathrm{H}-5,2-4 \mathrm{~cm}$, $-8 \mathrm{H}-3,114-116 \mathrm{~cm}$, and $-9 \mathrm{H}-6,7-9 \mathrm{~cm})$.

Morphologically, the manganese crusts closely resemble modern deposits recovered from the Valu Fa Ridge (Herzig et al., 1990) and the Tonga-Kermadec Ridge (Moorby et al., 1984), comprising either small brittle fragments with a purplish black metallic to submetallic luster and massive texture or small fragments of more granular, friable material with a porous texture. In addition, some fragments comprise manganese oxide-cemented volcanic ash and pumice, again typical of hydrothermal manganese crust from island arc settings (Usui and Nishimura, 1992). X-ray diffraction studies of crust fragments from Site 835 show it contains todorokite, again commonly reported in hydrothermal manganese crusts, whereas geochemically the deposits show a composition characteristic of hydrothermal manganese crusts, exhibiting high $\mathrm{Mn}$ contents (up to $46 \% \mathrm{Mn}$ ) with low concentrations of $\mathrm{Fe}, \mathrm{Co}, \mathrm{Ni}, \mathrm{Cu}, \mathrm{Zn}$, and $\mathrm{Pb}$ in comparison with hydrogenous manganese crusts.

At Site 838, the manganese crusts are all associated with redeposited sediments, namely pumiceous gravels or proximal reworked (slump) deposits (Parson, Hawkins, Allen, et al., 1992). Bednarz and Schmincke (this volume) postulated intrabasin eruptive sources for these deposits and, based on gross similarities in the geological/ volcanological evolution seen at backarc Sites 837-839, suggested a single source, possibly a seamount, as the most likely origin for these volcaniclastic sediment sequences. Based on such a provenance model, the hydrothermal manganese crusts probably formed originally on a nearby seamount within the basin and subsequently were incorporated into the volcaniclastic sediment sequence during redeposition. The association of hydrothermal manganese crusts with an "off-axis," intrabasin seamount has previously been reported in the Lau Basin by von Stackelberg et al. (1990).

At Site 835, the hydrothermal manganese crusts occur within ferromanganese oxide-stained clayey nannofossil ooze toward the base of the sediment section. Detailed lithologic logging has identified Section, 135-835A-17H-1,93-103 cm, as a redeposited sequence (turbidite), indicating that the crust fragments have been reworked. Morphologically, the fragments are small, but angular, with freshly broken surfaces, suggesting that they have not been transported over a long distance. Thus, they are probably from a proximal source.

\section{CONCLUSIONS}

The sedimentary succession recovered from the backarc sites ranges in age from the late Miocene to the Holocene. The succession consists of a lower sequence of volcaniclastic sediment gravity-flow deposits with interbedded hemipelagic clayey nannofossil mixed sediments and nannofossil clays. These beds are overlain by an upper sequence of hemipelagic clayey nannofossil oozes with minor calcareous turbidites. All the backarc sites show this same overall pattern of sedimentation.

The thickness of the lower volcaniclastic succession and the overlying clayey nannofossil ooze succession varies across the back-arc basin. The volcaniclastic sediments are predominantly massive, proximal vitric sands, silts, and gravels. These were probably derived from intrabasin seamount volcanoes and the numerous upstanding basement ridges (which include relict arc fragments and arc constructs) that separate the individual sub-basins of the horst-and-graben terrain forming the floor of the western Lau Basin.

Pliocene sedimentation in the backarc basin was characterized by proximal volcaniclastic sedimentation around intrabasinal seamount volcanoes, whereas Pleistocene sedimentation was mainly hemipelagic clayey nannofossil ooze.

In contrast to the other backarc sites, Site 835 was affected by marked instability throughout the Pleistocene, leading to extensive emplacement of muddy debris flows, rafted blocks, and thick mud turbidites. The most recent episode of instability at this site may correlate with the approach and passing of the Central Lau propagator. An episode of instability suggested by increased turbidite emplacement at Site 834 may also correlate with the approach and passing of the Central Lau propagator.

Geochemical analysis of individual glass grains from the volcaniclastic beds shows a subdivision of the backarc basin into three areas: a western group (Sites 834-835) that shows a broad spectrum of total silica values, a central group (Sites 837-839) that shows an approximately bimodal total silica population, and Site 836 , which has a 
strong bias to low-silica glasses. The geochemical subdivision corroborates the sedimentary evidence for depositional compartmentalization of the basin during the Pliocene.

The hemipelagic sediments in the backarc basin are pervasively stained moderate yellowish brown to dark yellowish brown throughout by hydrothermally derived iron and manganese oxyhydroxides. A similar trend in downhole variability in the hydrothermal oxide sediment component is seen at all backarc sites, with the possible exception of Site 836. A period of increased hydrothermal input occurs at depth at all sites, whereas above and below this, a general trend of decreasing hydrothermal input is seen. These trends probably reflect a lag time required for complete establishment of a hydrothermal system and its maximum input to the sedimentary sequence.

\section{ACKNOWLEDGMENTS}

We thank the shipboard scientific party, the ODP technicians, and the SEDCO drilling crew of Leg 135. We also thank U. von Rad for generously providing unpublished XRF data of volcaniclastic sediments recovered during Sonne cruises. This paper was improved by comments by Phil Weaver, David Barnes, and an anonymous reviewer, to whom we express our thanks.

\section{REFERENCES}

Barrett, T., Taylor, P.N., and Lugowski, J., 1987. Metalliferous sediments from DSDP Leg 92: the East Pacific Rise transect. Geochim. Cosmochim. Acta. $51: 2241-2253$

Cawood, P.A., 1991. Nature and record of igneous activity in the Tonga Arc. SW Pacific, deduced from the phase chemistry of derived detrital grains. In Morton, A.C., Todd, S.P., and Haughton, P.D.W. (Eds.), Developments in Sedimentary Provenance Studies. Geol. Soc. Spec. Publ. London, $57: 305-321$.

Cole, J.W., Gill, J.B., and Woodhall, D., 1985. Petrologic history of the Lau Ridge, Fiji. In Scholl, D.W., and Vallier, T.L. (Eds.), Geology and Offshore Resources of Pacific Island Arcs-Tonga Region. Circum-Pac. Counc. Energy Miner. Resour., Earth Sci. Ser., 2:379-414.

Cronan, D.S., Hodkinson. R.A., Harkness, D.D., Moorby, S.A., and Glasby, G.P. 1986. Accumulation rates of hydrothermal metalliferous sediments in the Lau Basin. S.W. Pacific. Geo-Mar. Lett., 6:51-56.

Gill, J., Torssander, P., Lapierre, H., Taylor, R., Kaiho. K., Koyama, M., Kusakabe. M., Aitchison. J., Cisowski, S., Dadey, K., Fujioka, K., Klaus. A., Lovell, M., Marsaglia, K.. Pezard. P.. Taylor. B., and Tazaki, K., 1990. Explosive deep water basalt in the Sumisu backarc rift. Science, 248:1214-1217.

Herzig, P.M., von Stackleberg. U., and Petersen, S., 1990. Hydrothermal mineralisation from the Valu Fa Ridge, Lau back-arc basin (SW Pacific). Mar. Min., 9:271-301.

Hodkinson, R.A., and Cronan, D.S., 1991. Geochemistry of recent hydrothermal sediments in relation to tectonic environment in the Lau Basin. southwest Pacific. Mar. Geol., 98:353-366.

Hodkinson, R.A., Cronan, D.S., Glasby, G.P., and Moorby, S.A. 1986. Geochemistry of marine sediments from the Lau Basin, Havre Trough, and Tonga-Kermadec Ridge, N.Z, J. Geol. Geophys., 29:335-344.

lizasa, K., Yuasa. M., and Yokata, S., 1992. Mineralogy and geochemistry of volcanogenic sulfides from the Myojinsho Caldera, the Shichito-Iwojima Ridge. Izu-Ogasawara Arc, northwestern Pacific. Mar: Geol., 108:39-58.

Kokelaar, B.P., 1986. Magma-water interactions in subaqueous and emergent basaltic volcanism. Bull. Volcanol., 48:275-289.

Lonsdale, P., and Hawkins, J.W., Jr., 1985. Silicic volcanism at an off-axis geothermal field in the Mariana Trough back-arc basin. Geol. Soc. Am. Bull.. 96:940-951.

Lyle, M., Owen, R.M., and Leinen, M., 1986. History of hydrothermal sedimentation at the East Pacific Rise, $19^{\circ}$ S. In Leinen, M.. Rea, D.K., et al., Init. Repts. DSDP, 92: Washington (U.S. Govt. Printing Office), 585-596.

Mazzullo, J.M., Meyer, A., and Kidd, R.B., 1987. New sediment classification scheme for the Ocean Drilling Program. In Mazzullo, J., and Graham.
A.G. (Eds.). Handlook for Shipboard Sedimentologists. ODP Tech. Note. $8: 45-67$.

Moorby, S.A., Cronan. D.S., and Glasby, G.P.. 1984. Geochemistry of hydrothermal Mn-oxide deposits from the S.W. Pacific island arc. Geochim. Cosmochim. Acta, 48:433-441.

Moorby, S.A., Knedler. K.E., Glasby, G.P., Hodkinson, R.A., and Cronan, D.S., 1986. Lithology, color, mineralogy and geochemistry of marine sediments of the Lau Basin, Havre Trough, and Tonga-Kermadec Ridge. N.Z. Oceanogr: Inst.. Field Rep., 27.

Muenow, D.W., Garcii. M.O., Aggrey, K.E., Bednarz, U., and Schmincke. H.-U., 1990. Volatiles in submarine glasses as a discriminant of tectonic origin: application to the Troodos ophiolite. Nature, 343:159-161.

Parson, L., Hawkins, J.. Allan, J., et al., 1992. Proc. ODP, Init. Repts., 135: College Station, TX (Ocean Drilling Program).

Pearce, J.A.. 1983. The role of sub-continental lithosphere in magma genesis at active continental margins. In Hawkesworth. C.J., and Norry. M.J. (Eds.), Continental Basalts and Mantle Xenoliths: Nantwich (Shiva Publ.), 230-249.

Peccerillo. A., and Taylor. S.R., 1976. Geochemistry of Eocene calc-alkaline volcanic rocks from the Kastamonu area, northern Turkey. Contrib. Mineral. Petrol.. 58:63-81.

Reich. V.. 1990. Calcareous ooze, volcanic ash, and metalliferous sediments in the Quaternary of the Lau and North Fiji basins. Geol. Jahrb., Reihe D. 92:109-162.

Reich, V.. Marchig, V.. Sunkel. G., and Weiss, W.. 1990. Hydrothermal and volcanic input in sediments of the Lau back-arc basin. S.W. Pacific. Mar: Min., 9:183-203.

Rodda, P., 1986. Home Reef pumice in Fiji. Fiji Miner. Resour. Dep. Note, BP I-58.

Shane, P.A.R., and Frogatt, P.C., 1991. Glass chemistry, paleomagnetism, and correlation of middle Pleistocene tuffs in southern North Island, New Zealand, and Western Pacific. N.Z. J. Geol. Geophys., 34:203-211.

Simonian, K.O., 1975. The geology of the Arakapas Fault Belt Area, Troodos Massif, Cyprus [Ph.D. thesis]. Open Univ., U.K.

Sun, S.-S., and McDonough. W.F., 1989. Chemical and isotopic systematics of oceanic basalts: implications for mantle composition and processes. In Saunders. A.D.. and Norry. M.J. (Eds.), Magmatism in the Ocean Basins. Geol. Soc. Spec. Publ. London, 42:313-345.

Sunkel. G.. 1990. Origin of petrological and geochemical variations of Lau Basin lavas (SW Pacific). Mar. Min.. 9:205-234.

Thomson, J., Higgs, N.C., and Colley, S., 1989. A geochemical investigation of reduction haloes developed under turbidites in brown clay. Mar. Geol., $89: 315-330$

Usui, A., and Nishimura, A., 1992. Submersible observations of hydrothermal manganese deposits on the Kaikata Seamount, Izu-Ogasawara (Bonin) Arc. Mar. Geol., 106:203-216.

von Rad, U., and Mühe, R., 1990. Mineralogy, chemical composition and origin of ash layers and pumice in sediments from the Lau and North Fiji basins (SW Pacific, SO-35 Cruise). Geol. Jahrb., Reihe D, 92:279-339.

von Stackelberg, U.. Marchig, V., Müller, P., and Weiser. T., 1990. Hydrothermal mineralisation in the Lau and North Fiji Basins. Geol. Jahrb., Reihe D. 92:547-613.

Walker, G.P.L., 1980. The Taupo Pumice: product of the most powerful known (ultraplinian) eruption. J. Volcanol. Geotherm. Res., 8:69-94.

Walter, P.. Stoffers, P.. Glasby. G.P.. and Marchig, V., 1990. Major and trace element geochemistry of Lau Basin sediments. Geol. Jahrb.. Reihe D, 92:163-188.

Williams, H., and Goles, G., 1968. Volume of the Mazama ash-fall and the origin of Crater Lake Caldera. In Dole. H. (Ed.), Andesite Conference Guidebook. Oregon State Dep. Geol. Miner. Indust, Bull., 62:37-4I.

\footnotetext{
Abbreviations for names of organizations and publication titles in ODP reference lists follow the style given in Chemical Abstracts Service Source Index (published by American Chemical Society).
}

Date of initial receipt: 13 January 1993

Date of acceptance: 9 July 1993

Ms 135SR-110 